\title{
Fu11-Scale Demonstration
}

\section{Low-NOx Cell Burner Retrofit}

Quarterly Report No. 2

for the period - January 1, 1991 through March 31, 1991

$$
\text { DOE Agreement No.: DE-FC22-9@PC90545 }
$$

B\&W CRD Agreement No.: CRD-1250

Patents Cleared by Chicago on July 3, 1991

\section{DISCLAIMER}

This report was prepared as an account of work sponsored by an agency of the United States Government. Neither the United States Government nor any agency thereof, nor any of their employees, makes any warranty, express or implied, or assumes any legal liability or responsibility for the accuracy, completeness, or usefulness of any information, apparatus, product, or process disclosed, or represents that its use would not infringe privately owned rights. Reference herein to any specific commercial product, process, or service by trade name, trademark, manufacturer, or otherwise does not necessarily constitute or imply its endorsement, recommendation, or favoring by the United States Government or any agency thereof. The views and opinions of authors expressed herein do not necessarily state or reflect those of the United States Government or any agency thereof.

Prepared by:

Babcock \& Wilcox

a McDermott Company

May 24, 1991 


\section{DISCLAIMER}

This report was prepared by Babcock \& Wilcox pursuant to a cooperative agreement partially funded by the U.S. Department of Energy and neither Babcock \& Wilcox nor any of its subcontractors nor the U.S. Department of Energy, nor any person acting on behalf of either:

(a) Makes any warranty or representation, express or implied, with respect to the accuracy, completeness, or usefulness of the information contained in this report, or that the use of any information, apparatus, method, or process disclosed in this report may not infringe privately-owried rights; or

(b) Assumes any liabilities with respect to the use of, or for damages resulting from the use of, any information, apparatus, method or process disclosed in this report.

Reference herein to any specific commercial project, process, or service by trade name, trademark, manufacturer, or otherwise, does not necessarily constitute or imply its endorsement, recommendation, or favoring by the U.S. Department of Energy. The views and opinions of authors expressed herein do not necessarily state or reflect those of the U.S. Department of Energy. 
1.0 Executive Summary

2.0 Introduction

3.0 Project Description

4.0 Project Status

5.0 Planned Activities (for next quarter)

6.0 Appendices

Appendix A - Numerical Modeling

Appendix B - Baseline Testing Results

Appendix C - Control System Design

Appendix D - Corrosion Test Panel 


\subsection{EXECUTIVE SUMMARY}

The Full Scale Demonstration Low-NOx Cell (LNC) Burner Project (DOE Agreement No. DE-FC22-90PC90545) progress from January 1, 1991 through March 31, 1991 identified in this, the second Quarterly Report. The Report centers on Phase I - Design, and Phase IIA - Procurement and Fabrication status.

The LNC Burner project involves retrofitting the two-nozzle cell burners at Dayt on Power \& Light's, 605 MWe J.M. Stuart Unit \#4 Boiler near Aberdeen, Ohio with LNC Burners (a burner and intregal NOx port). Previous pilot-scale tests have shown such an arrangement to achieve $50 \%$ reduction in NOx emission levels. This full-scale project will determine the commercial applicability of this technology.

Funding Agreements were signed with both Allegheny Power and the Ohio Coal Development Office (OCDO). The Electric Power Research Institute (EPRI) remains the only agreement to negotiate. The second advisory comittee meeting, which also served as the $90 \%$ Design Review Meeting, was held on March 12, 1991. Tours of DP\&L Stuart Station Unit \#4 were conducted as a sidelight to this meeting. As a result, committee members were able to inspect the LNC Burner equipment that is now on-site awaiting the outage.

Formal documentation for the cost plan and Operating \& Maintenance manuals as well as draft copies of the Project Evaluation Plan, the Detalled Work Plan, the Technical Progress Quarterly Report \#1, Preliminary Public Design Report and the Environmental Monitoring Plan were submitted to DOE PETC for review and approval.

Pre-retrofit testing emissions data has been analyzed and preliminary results delineated. Baseline NOx levels for DP\&L Stuart Station Unit \$4 firing the test Kentucky fuel is approximately 1.2 lbs of NOx/miilion Btu of input at full boller load with all mills in service and $20 \%$ excess air operation. Preliminary analysis of HVT flue gas temperature, flue gas velocity and $\mathrm{O}_{2}$ field test data taken during the Pre-Retrofit testing shows the Numerical Model prediction capability to be valid.

Laboratory testing work continues. Corrosion retort tests were started in February, 1991. The test conditions will vary alloy composition, coating processes, gas temperatures and mixed gas composition with variable $\mathrm{H}_{2} \mathrm{~S}$ levels. The retort tests will be completed by August, 1991.

Dayton Power \& Light has finalized design and procurement of the control system upgrade equipment necessary to handle LNC Burner operation. All of the fabricated equipment for the LNC Burner System, except for ceramic piping, is complete and has been shipped to the jobsite. All shipments will be completed by June, 1991 . 


\subsection{INTRODUCTION}

As per the Cooperative Agreement No. DE-FC22-90PC90545 dated October 11, 1990, the following quarterly report has been prepared for Phases I and IIA of the Full-Scale Demonstration of Low NOx Cell Burner Project. The period covered by this quarterly report is January 1, 1991 through March 31, 1991. This report is the second quarterly prepared for the project.

Phase I - Design work accomplished during this quarter follows. Under Task 1 - Management \& Reporting, formal documentation for the cost plan and Operating \& Maintenance manuals as well as draft coples of the Project Evaluation Plan, the Detalled Work Plan, the Technical Progress Quarterly Report $\|_{1}$, Preliminary Public Design Report and the Environmental Monftoring Plan were submitted to DOE PETC. Funding Agreements were signed with both Allegheny Power and the Ohio Coal Development Office (OCDO). Additionally, the second advisory committee meeting was held on March 12, 1991. Under Task 3 - Pre-Retrofit Testing, baseline test data analysis and pre-retrofit test report writing was initiated. Laboratory Corrosion testing work continued with the major emphasis on alloy/H $\mathrm{H}$ retort test work. Actual baseline test data results were compared to the predicted results from numerical modelling of the standard cell burner. The $90 \%$ Design Review milestone involving Task 4 - Functional Engineering \& Task 5 - Detailed Design Engineering was completed. Activities in Task 2 - Test Plan Development, and Task 6 Permitting were concluded last quarter.

Phase IIA - Procurement and Fabrication work accomplished during this quarter for Task 1 - Management \& Reporting centered around discussions for a workscope change to install a corrosion test panel. Work under Task 3 Manufacturing \& Fabrication shows all materials, except for ceramic piping, completed and shipped to the jobsite.

The major components of this report deal with the preliminary results of Phase I, Task 3 - Pre-Retrofit Testing. 


\subsection{PROJECT DESCRIPTION}

\subsection{PROJECT OVERVIEW}

The current energy policy of the United States includes the expanded use of coal in utility and industrial applications. However, the increased use of coal must nct conflict with environmental goals and thus requires development of cost-effective technology to control the pollutants resulting from coal combustion. Of major concern is the problem of oxides of nitrogen in the Northeastern United States and portions of Canada.

U.S.-Installed steam generating units (1e. boilers) equipped with pulverized-coal-fired, cell-type burners account for approximately 26,000 MW of electric power generating capacity. Ten thousand MW of generating capacity is located in Ohio. The balance is located primarily in the Midwest and Northeast, but also in the South and West. Coal-fired generating units equipped with cell-type burners produce about $20 \%$ of the Pre-New Source Performance Standards (NSPS) uttlity NOx emissions with an uncontrolled emission rate of approximately $1,000,000 \mathrm{t} / \mathrm{yr} \mathrm{NOx}$ as $\mathrm{NO}_{2}$. Replacement of the standard cell burners with Low-NOx Cell (LNC) burners can potentially reduce NOx emissions by $50 \%$ per boiler, or 500,000 600,000 tons per year if applied to all pre-NSPS bollers of this type.

Currently there is no other commercially-avallable technology that can achieve NOx emission reductions on the order of $50 \%$ in cell-fired utility boilers without resorting to pressure part modifications. The unique cell burner configuration preciudes the use of commercially-available low-NOx burner designs. This is due to the proximity of the burner throats and the relatively small burner throat openings typical of the pre-NSPS cell burner design. Low-NOx burner designs operating on the principle of delayed combustion require larger throat openings, i.e., lower burner air velocities, to inhibit the formation of volatile NO in the eariy stages of combustion. Furthermore, optimum NOx reduction with standard low-NOx burner designs is achieved when heat release rate per unit volume is minimized. The existing cell burner configuration does not lend itself to either of these requiraments.

Realizing the need, Babcock \& Wilcox and the Electric Power Research Institute (EPRI) have invested a large amount of resources in the research and development of an unique, "plug in" Low-NOx Cell burner for retrofitting these existing bollers equipped with standard cell burners. Refer to Appendix A for sketches showing existing sitandard cell burner arrangement versus the proposed low-NOx cell burner arrangement.

\subsection{PROJECT BACKGROUND}

The low-NOx cell burner operates on the principle of staged combustion. The lower burner of each two-nozzle cell is modified to accommodate all the fuel input previously handled by two nozzles. Secondary air, less than theoretically required for complete combustion, is introduced to the lower burner. The remainder of secondary air is directed to the upper "port" of each cell to complete the combustion process. 
B\&W/EPRI have thoroughly tested the LNC burner at two pilot scales (6 million Btu per hour and 100 million Btu per hour), and tested a single full-scale burner in a utility boiler. Combustion tests at two scales have confirmed NOx reduction with the low-NOx cell on the order of $50 \%$ relative to the standard cell burner at optimum operating conditions. The technology is now ready for full unit, full-scale demonstration.

From the standpoint of a cost-effective NOx reduction technology the low-NOx cell burner is, by design, ideally suited for retrofit to existing two-nozzle cell burner installations. The "plug-in" design will fit existing wall tube openings eliminating outage time and material/ labor expense associated with pressure part modifications and burner relocetinns. Potentially, this burner can be installed on all utility boilers currently equipped with two-nozzle cell burners, and can be adapted to units with three-nozzle cell burners.

Since pressure part changes are not required for the replacement, low-NOx cell burners are the most cost-effective NOx control alternative for bollers equipped with standard cell burners. The cost effectiveness (dollars per ton NOx removal) for the low-NOx cell burners is about one-half of that for conventional low-NOx burners, and one-tenth that for selective catalytic reduction.

The low-NOx cell burner retrofit is expected to be compatible with all U.S. coals currently being burned in the original cell burners. No loss to domestic coal sourcing will be recognized. Utilities representing $70 \%$ of the potential low-NOx cell burner retrofit market (capacity basis) are participating in the project.

To accelerate commercialization of this promising technology in controlling NOx levels in pre-NSPS power plants, a full-scale retrofit of a complete boller system is to be performed. This project at Dayton Power \& Light's J.M. Stuart Unit \#4, located along the Ohio River between Manchester and Aberdeen, Ohio, will permit actual full-scale NOx levels to be quantified and demonstrate the ability of the equipment to rellably meet conservative utility industry standards.

Unit No. 4 is a supercritical Universal Pressure, single-reheat, Carolina-type boller, fired with pulverized coal. The unit is designed for a maximum continuous capacity of $4,400,000 \mathrm{lbs}$ steam $/ \mathrm{hr}$ delivered to a 3500 psig (nominal) General Electric turbine-generator for a maximum gross generating capacity of 605 MWe.

Existing combustion equipment consists of 24 two-nozzle cell burners, 6 MPS-89K pulverizers, and 6 gcavimetric feeders. The burners are arranged in an opposed-fired configuration with 12 cell burners on each wall, 2 high by 6 wide. The existing burner throat openings are 38 inches in diameter.

\subsection{PROJECT OBJECTIVES}

The overall objective of the Full-Scale Low-NOx Cell (LNC) Burner Retrofit project is to demonstrate the cost-effective reduction of NOx generated by a large, base-loaded ( $70 \%$ capacity factor or greater), coal-fired utility boller. Specific objectives include: 
- At least $50 \%$ NOx reduction over standard two-nozzle cell burners, without degradation of boller performance or life.

- Acquire and evaluate emission and boller performance data before and after the retrofit to determine NOx reduction and impact on overall boiler performance.

- Demonstrate that the LNC burner retrofits are the most cost-effective alternative to emerging, or commerclally-available NOx control technology for units equipped with cell burners.

The focus of this demonstration is to determine maximum NOx reduction capabilities without adversely impacting plant performance, operation and maintenance. In particular, the prototype evaluations will resolve many technical issues not possible to address fully in the previous pilot-scale work and the single full-scale burner installation. These include low-NOx combustion system Impact on:

(1) boiler thermal efficiency

(2) furnace temperature and heat absorption profiles

(3) slagging and fouling

(4) waterwall corrosion

(5) gaseous and particulate emissions

(6) boiler operation considerations

\subsection{HOST SITE BOILER}

The host site is an existing utility boller owned by Dayton Power \& Light Company, Cincinnati Gas \& Electric Company, and Columbus Southern Power

Company. The following is a summary of pertinent information.

- OPERATING UTILITY: The Dayton Power \& Light Company

- UNIT ID: J.M. Stuart No. 4

- LOCATION: Route 52, P.0. Box 468

Aberdeen, Adams County, Ohio 45101

- NAME PLATE RATING: 605 MW NDC

- TYPE: Tandem Steam Turbine

- PRIMARY FUEL: Eastern Bituminous Pulverized Coal

from Ohio, West Virginia, and Kentucky

- OPERATION DATE: 1974

- BOILER ID: Babcock \& Wilcox UP No. 106

- BOILER GENERAL CONDITION: Commercial Operation/Good Condition

- BOILER TYPE: Supercritical, Once-Through

- DEMONSTRATION FUEL: Eastern Bituminous Pulverized Cozl 


\subsection{PROJECT TEAM}

The Low NOx Cell Burner Project Team consists of the U.S. Department. of Energy, The Babcock \& Wilcox Company, Dayton Power \& Light, the Electric Power Research Institute (EPRI).

Team members from B\&W represent the Research and Development Division (R\&DD), the Fossil Power Division (FPD), the Energy Service Division (ESD) and the Contract Research Division (CRD).

Major subcontractors are Acurex and a yet unassigned installation contractor. Acurex has been designated to perform continuous emissions monitoring activiries as well as various analytical requirements during the testing program. The installation subcontractor will be the Dayton Power \& Light J.M. Stuart Station maintenance contractor. They will perform pre-outage, outage, and start-up work necessary to install the Low-NOx Cell Burners and its associated equipment.

A summary of the overall projact organization is as follows:

\section{Project Organization}

- Department of Energy - 48.4\% funding co-sponsor

- Babcock \& Wilcox - Prime contractor, project manager, and funding co-sponsor

- Dayton Power \& Light - Host site utility and funding co-sponsor

- EPRI - Technizal advisor and funding co-sponsor

- Ohio Coal Development Office - Advisory committee member and funding co-sponsor

- Utility advisory committee members and funding co-sponsors

Allegheny Power System

Centerior Energy Corporation - Funding thru EPRI

Duke Power Company - Funding thru EFRI

New England Power Company - Funding thru EPRI

Tennessee Valley Authority - Funding thru EPRI

- Acurex Corporation - testing subcontractor

- DP\&L Stuart Station Maintenance Contractor - LNCB Installation 


\subsection{PROJECT PHASES}

The LNC Burner project, which is a $\$ 9.796$ million profect, consists of four separate phases which are planned to occur over a 32-month period. These are:

- Phase I - Design

During this phase, the Low-NOx Cell (LNC) Burner System will be designed based upon B\&W's pilot-scale combustion tests, and experience/knowledge of full-scale burner/OFA port/control system retrofits. Additionally, collection of baseline emissions and performance data, along with performance of general bofler system assessment, will be completed at DP\&L's J.M. Stuart Unit \#4 prior to the LNC Burner retrofit.

- Phase IIA - Procurement \& Fabrication

In order to meet the construction schedule, long lead-time equipment will be ordered and fabricated during the first budget period. To facilitate the funding of this procurement activity, Phase II is divided into two parts, Phase IIA and Phase IIB.

- Phase IIB - Installation

The LNC Burner system will be installed and started up to provide a fully operational system prior to testing.

- Phase III - Operation

Parametric/optimization and long term performance tests will assess the potential of the technology from both the resulting emission reductions and boller performance capability aspects. Both full-load and reducedload operations will be evaluated for the LNC Burner technology. Finally, readiness for commercialization will be determined from both a technical and economic viewpoint. 


\subsection{PROJECT STATUS}

The time period covered by this project quarterly report $\|_{2}$ is January 1, 1991 through March 31, 1991. Progress will be discussed on a task basis for each of the Phase I and Phase IIA activities.

\subsection{PHASE I - DESIGN}

Activities in Phase I include the following tasks: Management and Reporting, Test Plan Development, Pre-Retrofit Testing, Functional Engineering, Detailed Design Engineering, and Permitting.

\subsubsection{Task 1 - Management and Reporting}

Dayton Power \& Light has found it necessary to delay the Stuart Station Unit \#4 outage. The outage will shift from the planned Spring, 1991 date to a September 22, 1991 start date. As a result, a request was submitted to DOE for a six-month extension to the first budget period. DOE approved an extension to August 30,1991 for the first budget period and an extension of project completion to May 31, 1993.

Monthly reports covering the time period of this report were completed and issued to DOE PETC on schedule. Formal documentation for the cost plan as well as Operating \& Maintenance manuals were submitted to DOE PETC.

Additionally, draft copies of the Project Evaluation Plan, the Detalled Work Plan, the Technical Progress Quarterly Report \#1, Preliminary Public Design Report, and the Environmental Monitoring Plan were also submitted during this period.

Funding Agreements were signed with both Allegheny Power and the Ohio Coal Development Office (OCDO). The Electric Power Research Institute (EPRI) remains the only agreement to negotiate.

The second advisory committee meeting was held on March 12, 1991 at the Drawbridge Inn, Cincinnat1, Ohio. The meeting was utilized as the Design Review Meeting. Tours of DP\&L Stuart Station Unit \#4 were conducted and on-site fabricated materials were inspected.

\subsubsection{Task 2 - Test Plan Development}

The final Pre-Retrofit TeBt Plan was approved by DOE. The plan identifies all test parameters, sampling instrumentation, equipment location, test date forms, test procedures, and testing matrix for both the baseline pre-retrofit tests and the Low-NOx Cell Burner Tests.

\subsubsection{Task 3 - Pre-Retrofit Testing}

Task 3 includes planning ard coordination, diagnostic testing and baseline characterization (unit condition assessment, boiler modifications for baseline testing numerical modeling, continuous emissions monitoring system (CEMS) installation, data acquisition equipment purchase and installation, baseline testing, laboratory testing), and completion of a Pre-Retrofit Test Report.

Most of the subtasks deftned above were completed prior to the period covered by this report. Only those subtasks involving ongoing work are reported below.

QR.2-4 


\subsubsection{Subtask 3.2 - Diagnostic Testing and Baseline Characterization}

\section{Numerical Modeling}

HVT flue gas temperature, flue gas velocity and $0_{2}$ data taken during the Pre-Retrofit testing was analyzed and then compared to model predictions. As can be seen in appendix $A$, the predicted data compares favorably to the actual fiuld data. Some extremes in the data points are attributable to slag and ash build-up on the probe, thereby distorting the readings.

\section{Baseline Testing}

The coal utilized during the pre-retrofit testing was restricted to coal from one Kentucky mine. This same coal is planned for use during post-retrofit optimization testing. DP\&L normally utilizes coal pile blending of their West Virginia and Kentucky coals with Ohio coal to a ratio of approximately $10 \%$ Ohio coal. The limit on use of Ohio Coal is due to sulfur emission regulations. It would be very difficult to characterize a coal pile blend, therefore, coal type was restricted during baseline testing and will again be restricted during optimization testing. Long term testing will utilize DP\&L's normal blended coal.

Pre-retrofit testing data has been analyzed and preliminary results have been delineated. Cell type bollers exhibit NOx levels in the range of 1.0 to 1.8 Ibs/million Btu of input. As the field test results located in appendix $B$ show, baseline NOx levels for DP\&L Stuart Station Unit $\# 4$ firing the test Kentucky fuel is approximately $1.2 \mathrm{lbs}$ of NOx/million Btu of input at full boiler load with all mills in service and $20 \%$ excess afr operation. Lower furnace $\mathrm{N}_{2} \mathrm{O}$ and $\mathrm{H}_{2} \mathrm{~S}$ levels were negligible.

\section{Laboratory Testing}

Laboratory Corrosion Testing work continues. The object of this subtask is to conduct retort tests of various candidate alloys by exposing them to simulated low-NOx combustion gases at different $\mathrm{H}_{2} \mathrm{~S}$ concentrations and temperatures. The low-NOx flue gas compositions were determined by theoretical calculations of coal combustion at predicted afr/fuel stoichlometric ratios. These compositions are being simulated in the laboratory and used for the corrosion retort tests.

The retort tests were started in February 1991. A total of 18 materials, including carbon steel, alloy steels, stainless steels, and coating systems, are being exposed to the simulated LNCB mixed gases. It is anticipated that five or six retort tests, each lasting 1000 hours, will be completed in the next 7 months. The test conditions vary in alloy composition, coating process, temperature $(500,700$, and $900 \mathrm{C})$ and mixed gas composition $(0.05$, 0.25 , and $\left.0.5 \% \mathrm{H}_{2} \mathrm{~S}\right)$.

Combining the prospective results from the laboratory tests with the corrosion data already avallable from previous B\&W studies, a corrosion model will be originated and the corrosion rates of candidate alloys under LNCB environments will be predicted. 


\subsubsection{Task 4 - Functional Engineering}

The $90 \%$ Design Review Meeting was held on March 12, 1991. Also, a draft of the Preliminary Public Design Report has been submitted for DOE PETC review and comments. The finalized sopy will be released in May, 1991.

\subsubsection{Task 5 - Detailed Design Engineering}

The $90 \%$ Design Review Meeting was held on March 12, 1991. A draft of the Final Public Design Report will be submitted for DOE PETC review and comments in June, 1991.

Dayton Power \& Light has finalized control system upgrades as noted in Appendix C. The extent of control system modifications will be plant specific. Therefore, the changes shown here may not apply to other boiler installations equipped with cell burners.

\subsubsection{Task 6 - Permitting}

This task is complete.

\subsection{A Phase IIA - Procurement and Fabrication}

Activities in Phase IIA include the following tasks: Management and Reporting, 'rocurement, and Manufacturing and Fabrication.

\subsection{A.1 Task 1 - Management and Reporting}

A meeting was held with DP\&L, DOE PETC, and B\&W to discuss possible modifications to the corrosion test plan:. A corrosion test panel with various corrosion resistant materials applied to the external tube face is being proposed. Suggested panel layout is shown in Appendix D. Additionally, there are areas in the DP\&L Stuart Uni: \#4 that w1ll need to be sandblasted to provide a base metal surface for ultrasonic testing. DP\&L has installed Aluminized spray coated panels in the areas of the furnace that are of interest regarding corrosion analysis. Removal of the coating is required to ascertain rates of corrosion of the base metal for a one year operation.

B\&W is still evaluating options and costs to provide the best technical and most cost effective approach. Funding sources are also being sought for this work addition.

\subsection{A.2 Task 2 - Procurement}

All raw material and sublet fabricated material procurement order work was completed last quarter.

\subsection{A.3 Task 3 - Manufacturing and Fabrication}

Manufacturing of the Low-NOx Cell Burners is complete and all twenty-four burners have shipped to the job site. Additionally, the following auxiliary equipment was fabricated and delivered to the jobsite. . .non-ceramic coal piping, coal pipe knife gate valves, support steel, support rods and hangers.

The ceramic piping fabrication has been delayed. The vendor expects to complete shipment by June, 1991 . 


\subsection{PLANNED ACTIVITIES}

Planned activities for the next quarter, April, May, and June 1991 will focus on completing the Environmental Monitoring Plan, the Project Work Plan, the Project Evaluation Plan, Project Evaluation Report, Public Design Reports, and the Baseline Test Report. In addition, based upon the near completion of first budget period activities, a Continuation Application Request will be submitted for approval.

Phase IIA, Task 3 - Manufacturing and Fabrication will be continued towards the expected completion date of June, 1991. 
APPENDIX A 


\section{Numerical Modeling Status}

March 12, 1991

- Validation Activities

- Comparison of Predictions and Data

- Conclusions

- Future Work 


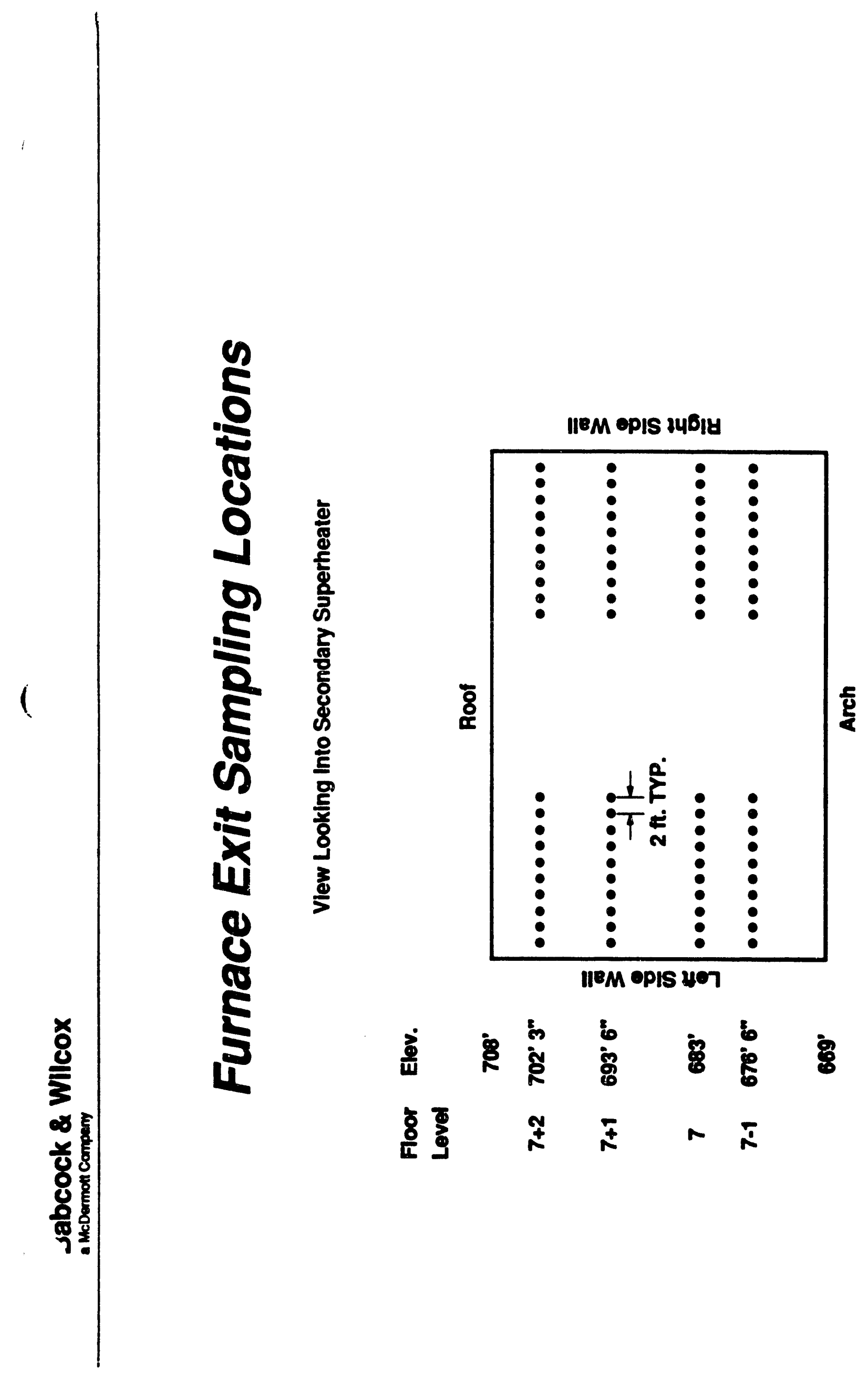




\section{Velocity Magnitudes, Gas Temperature and Oxygen Concentration 40 ft. Above the Burners for Full Load}

Volocity Magnitude (ft/sec)

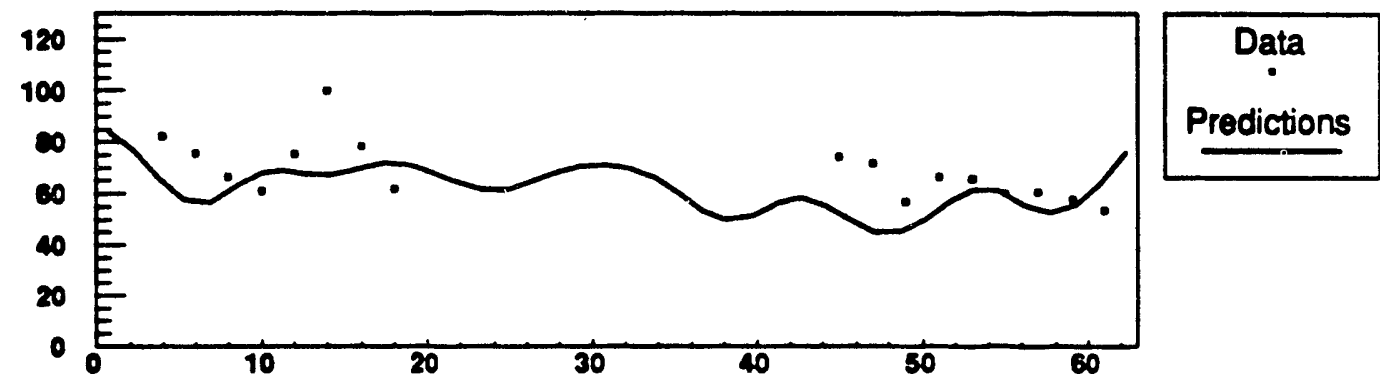

Gas Tomperature - MHVT (F)

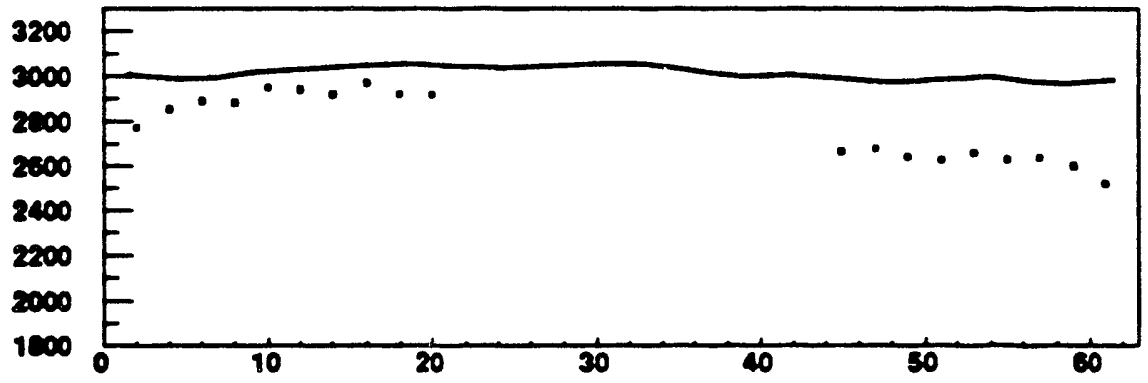

Oxygen Concentration (ppmey) \%

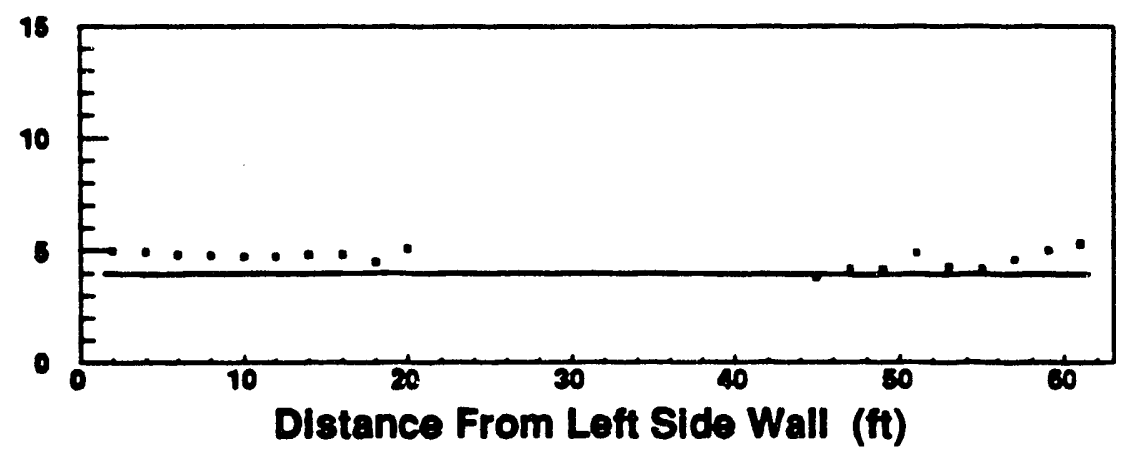




\section{Velocity Magnitudes, Gas Temperature and Oxygen Concentration 40 ft. Above the Burners for Intermediate Load "}

Velocity Magnitude (ft/sec)

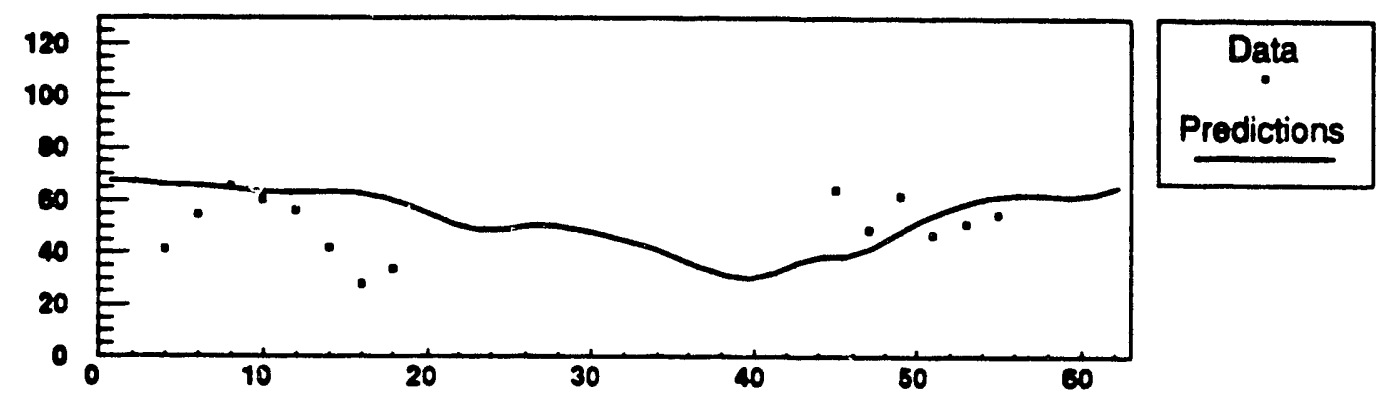

Gas Temperature - MHVT (F)

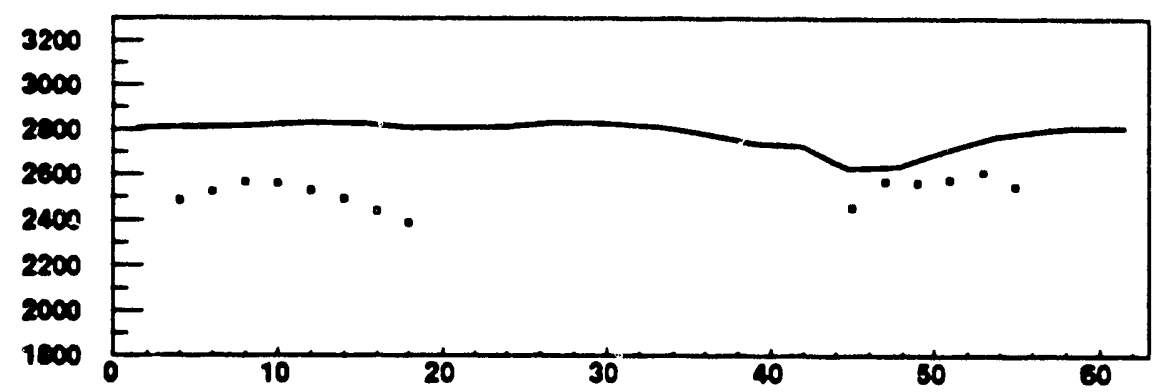

Oxygen Concentration (ppmt) $\%$

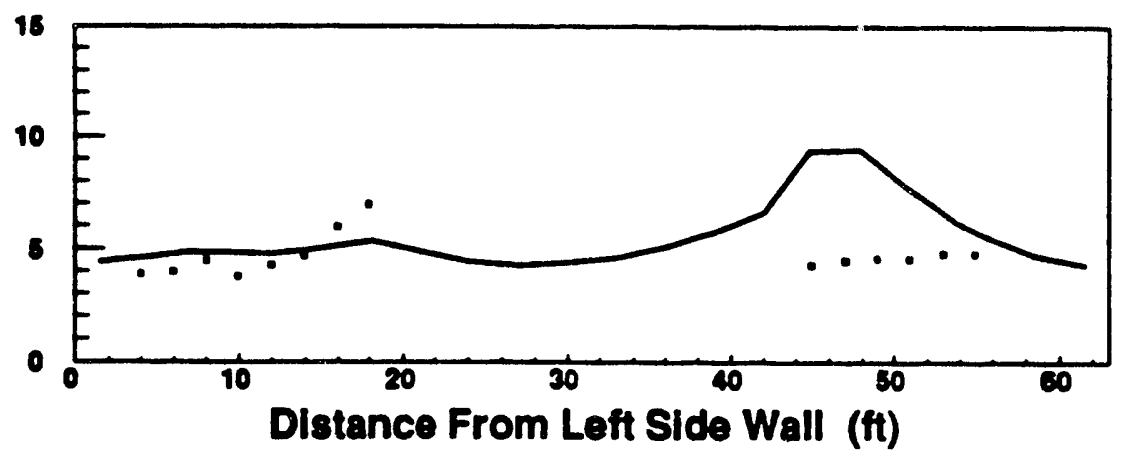




\section{Velocity Magnitudes at the Furnace Exit Plane for Full Load}

Floor $7+2$
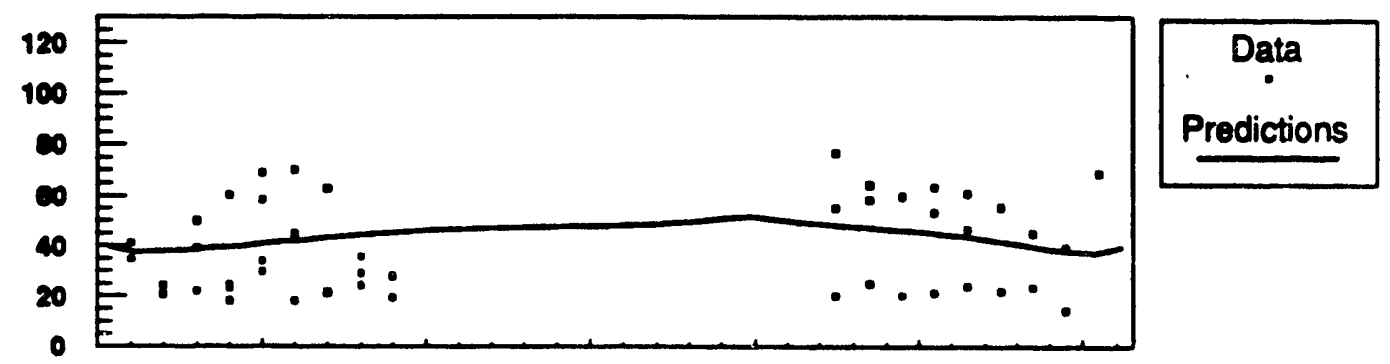

Floor $7+1$

Floor 7

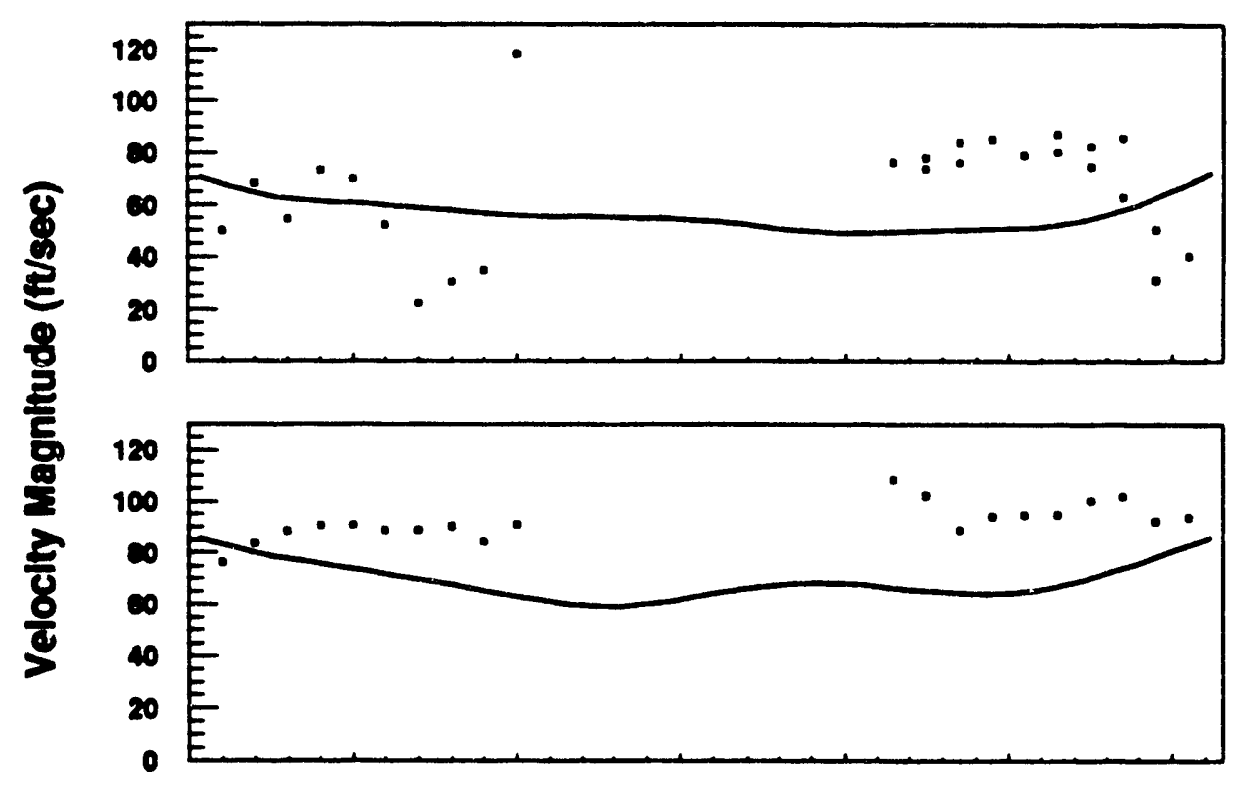

Floor 7-1

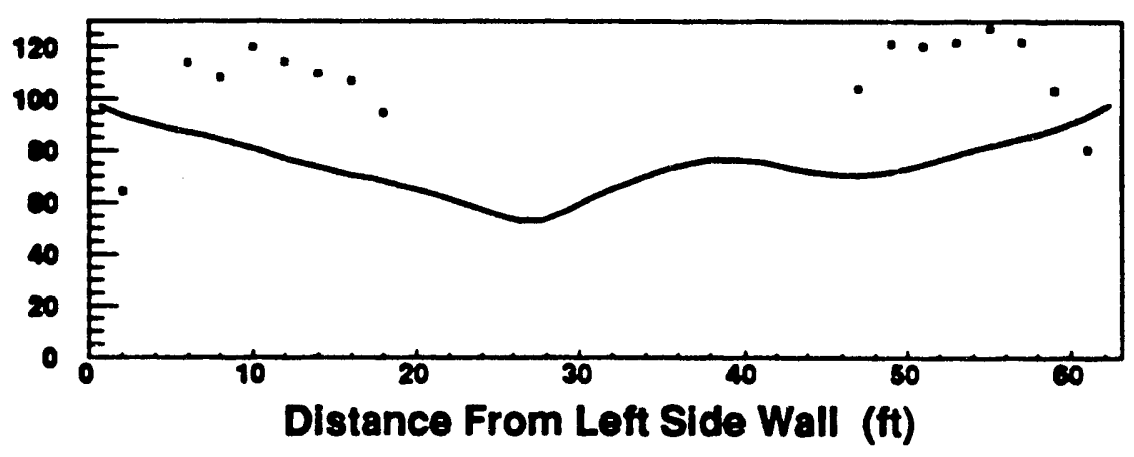




\section{Furnace Exit Gas Temperatures for Full Load}

Floor $7+2$
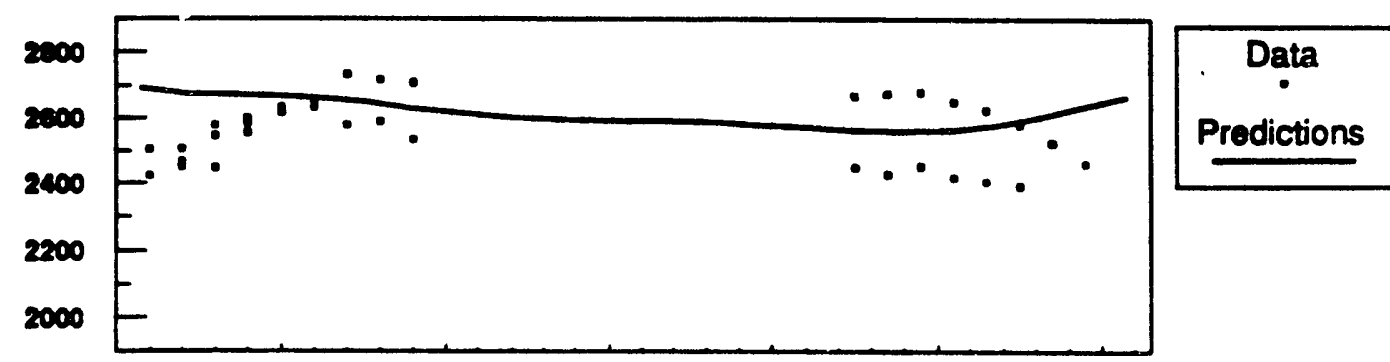

Floor $7+1$

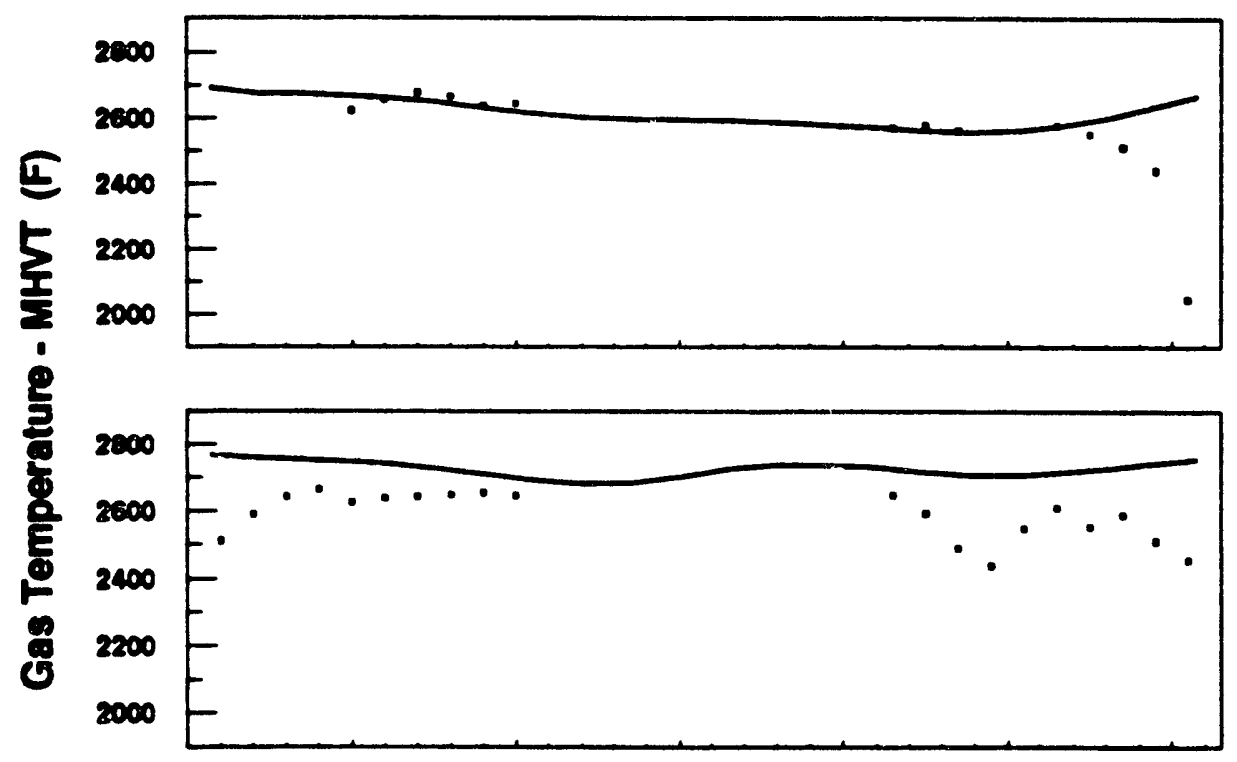

Floor 7-1

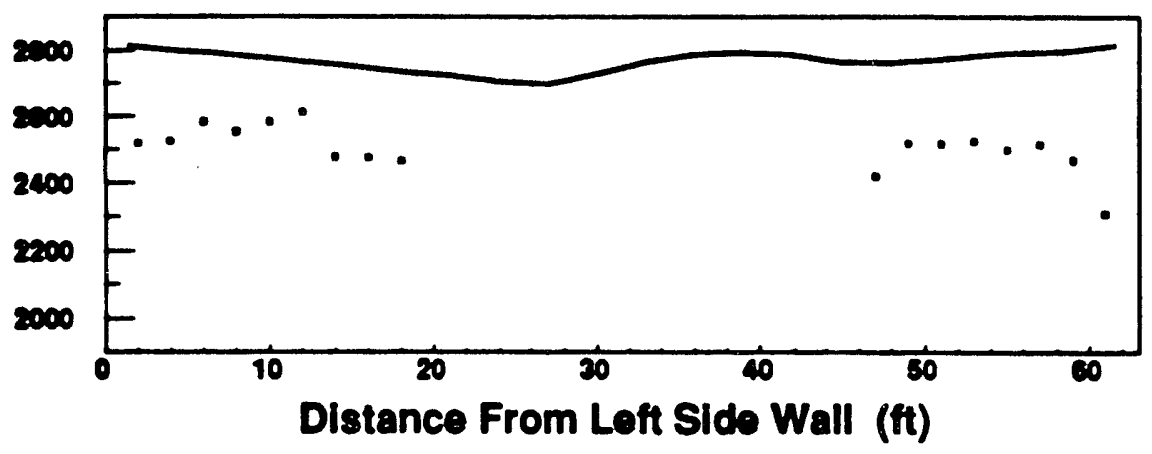


Tabcock \& Wilcox

.cDermott Company

Oxygen Concentration at the Furnace Exit for Full Load

Floor $7+2$
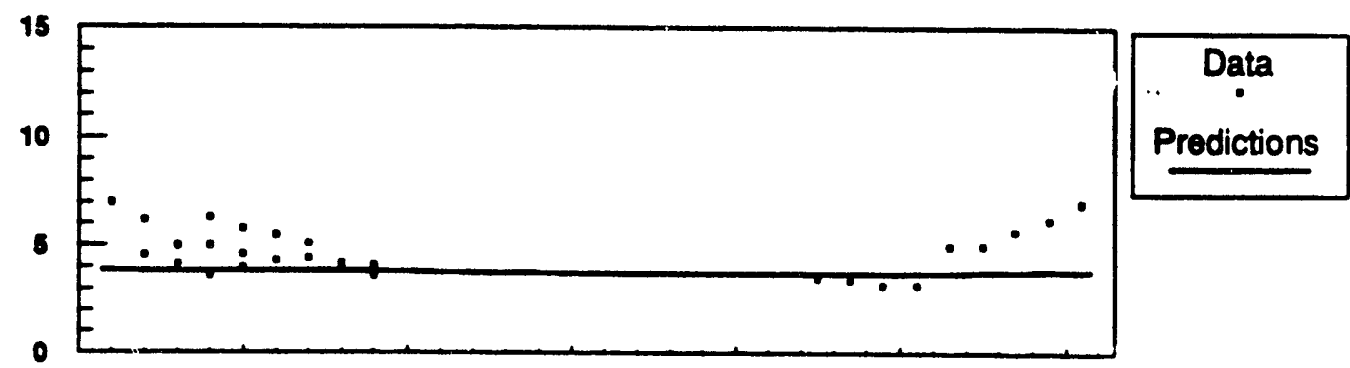

Floor 7

Floor 7-1
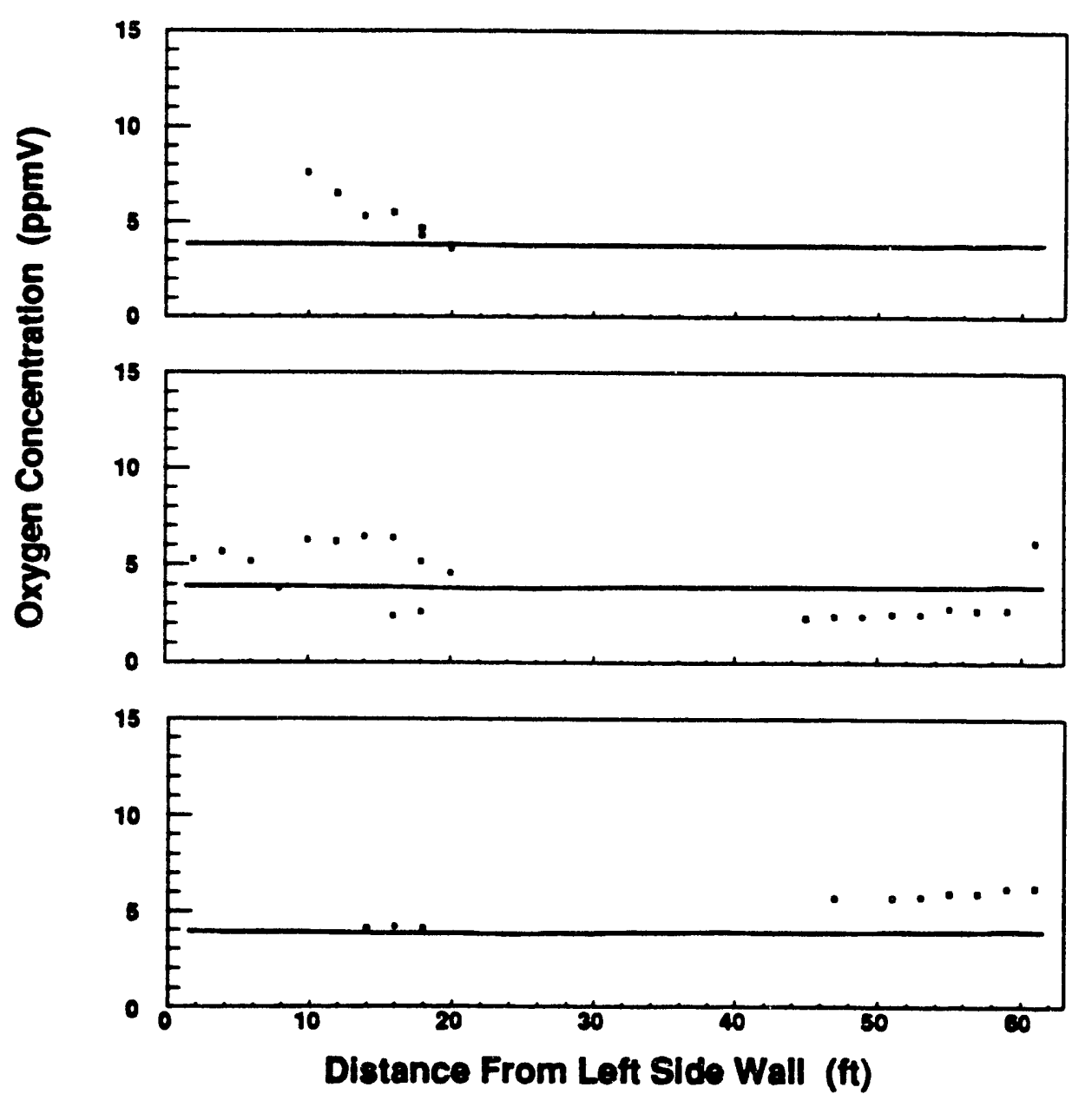


\section{Velocity Magnitudes at the Furnace Exit Plane for Intermediate Load}

Floor $7+2$

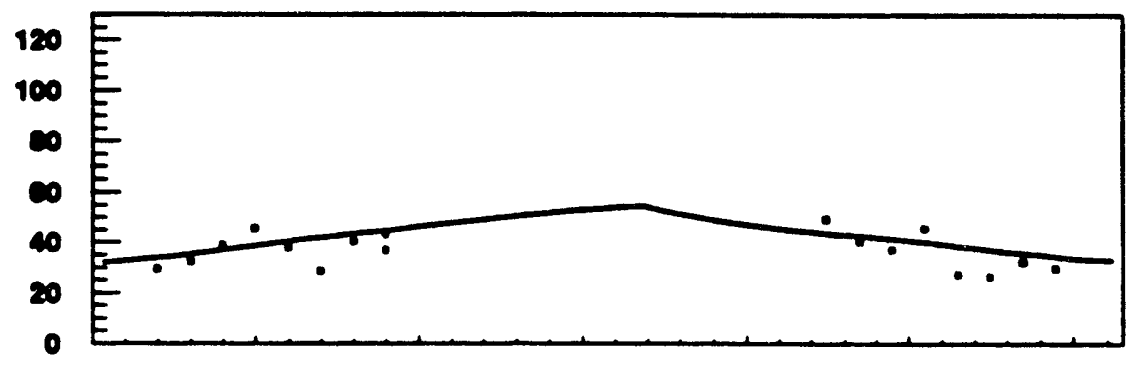

\begin{tabular}{|c|}
\hline Data \\
Predictions \\
\hline
\end{tabular}

Floor $7+1$

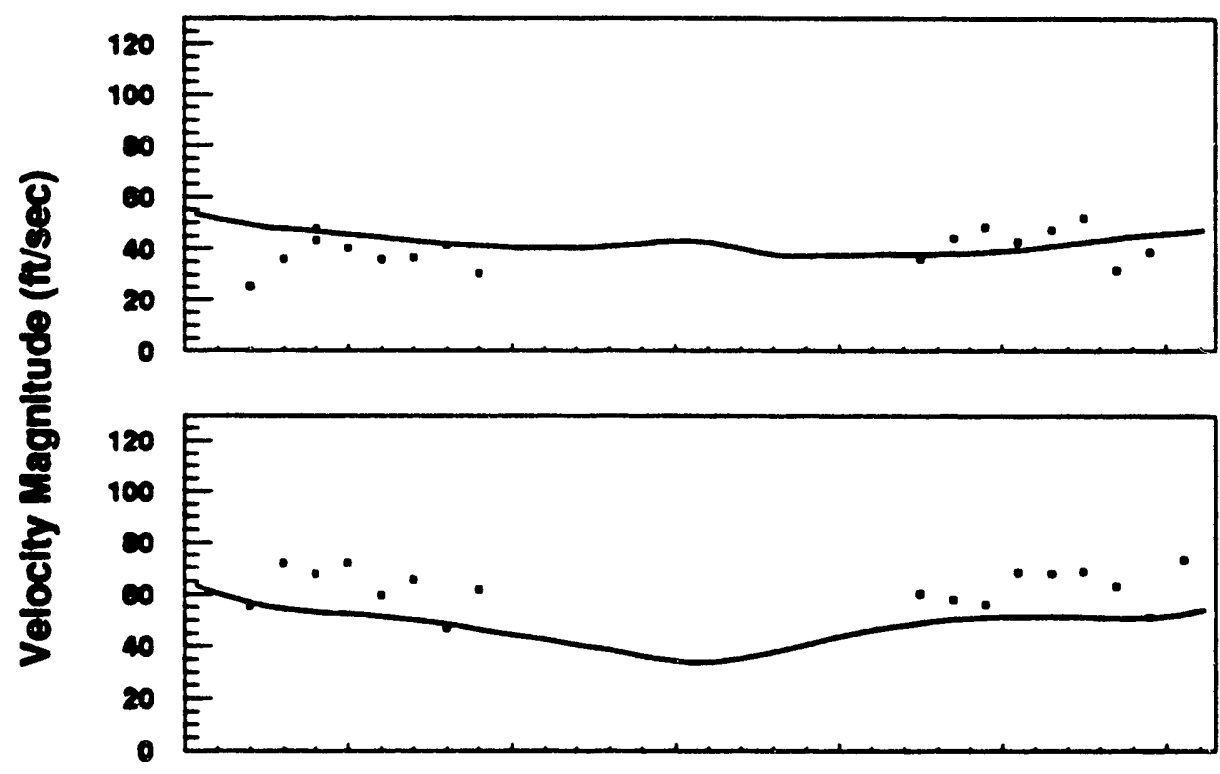

Floor 7-1

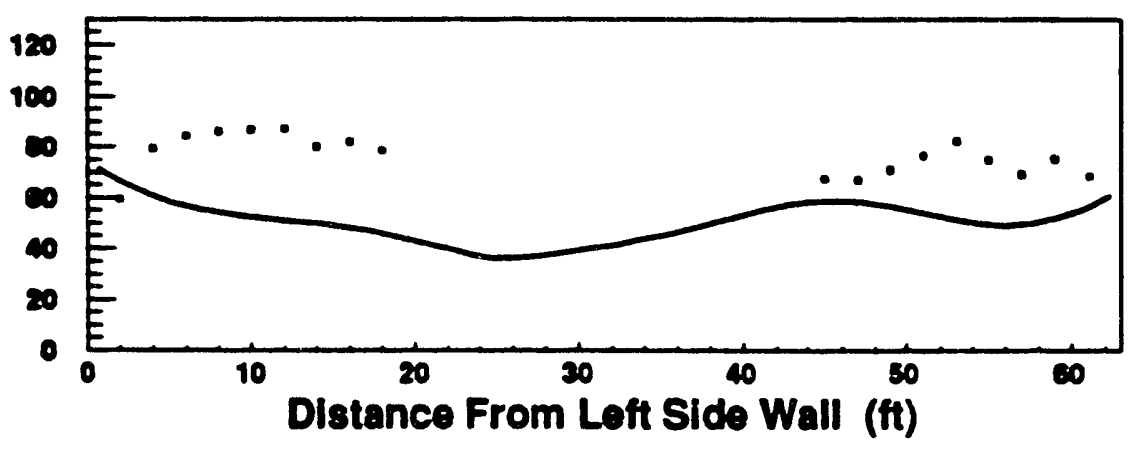




\section{Furnace Exit Gas Temperatures for Intermediate Load}

Floor $7+2$

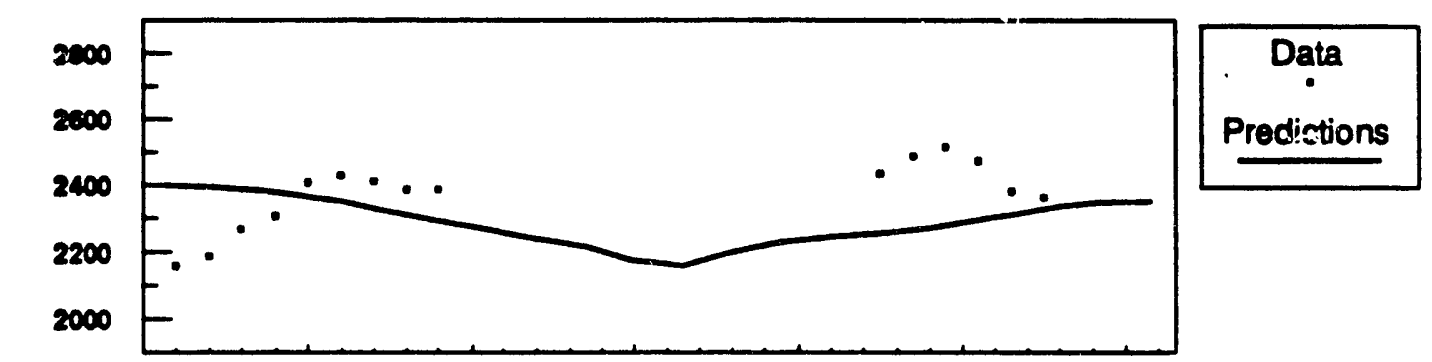

Floor $7+1$

Floor 7

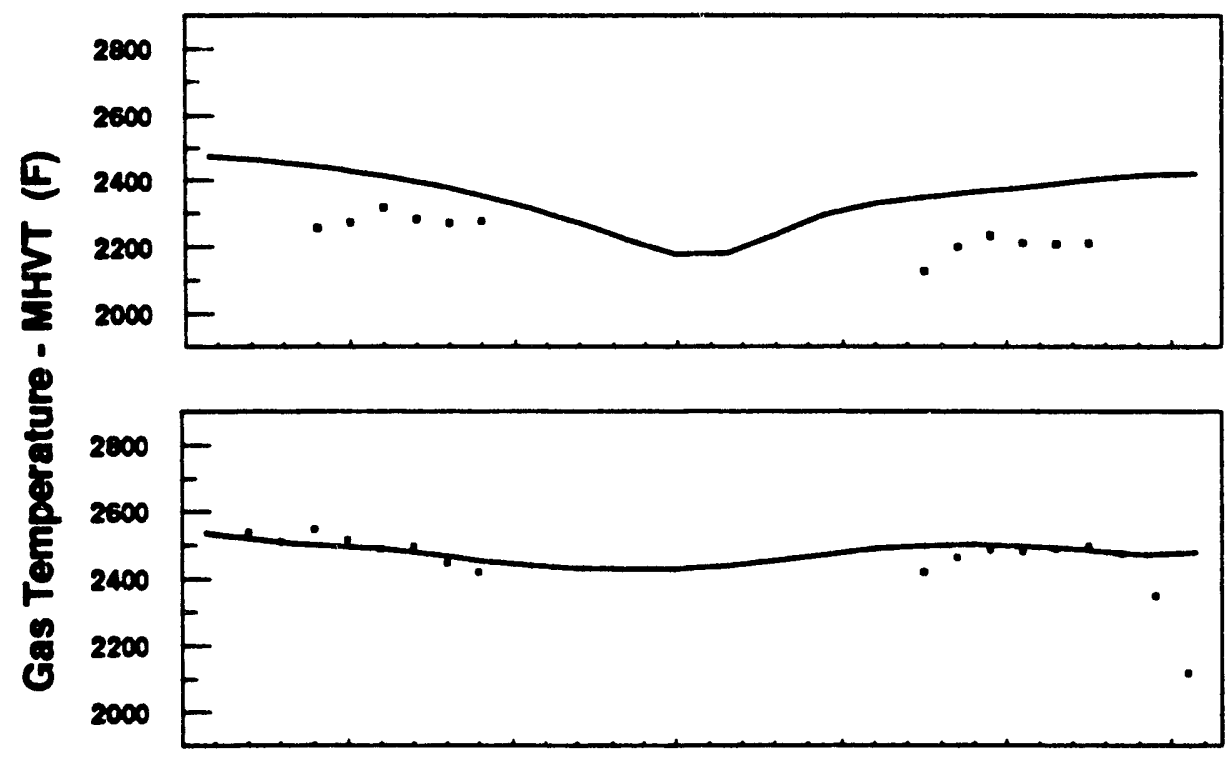

Floor $7-1$

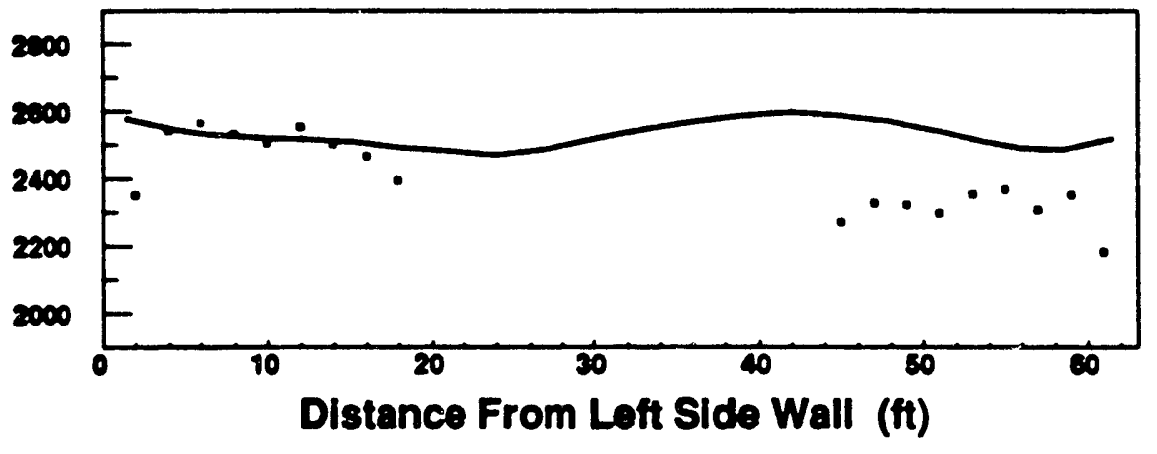




\section{Oxygen Concentration at the Furnace Exit for Intermediate Load}
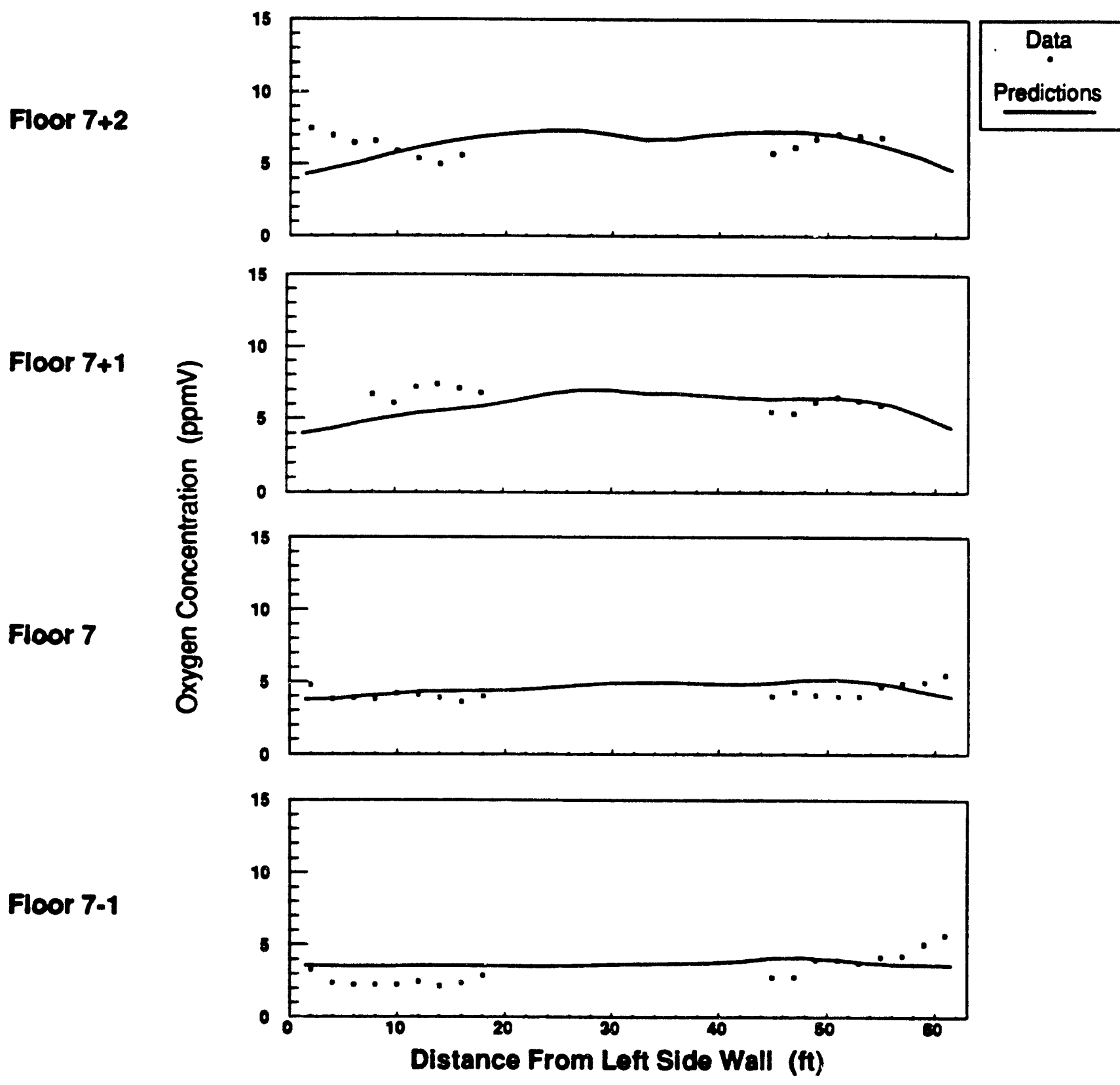


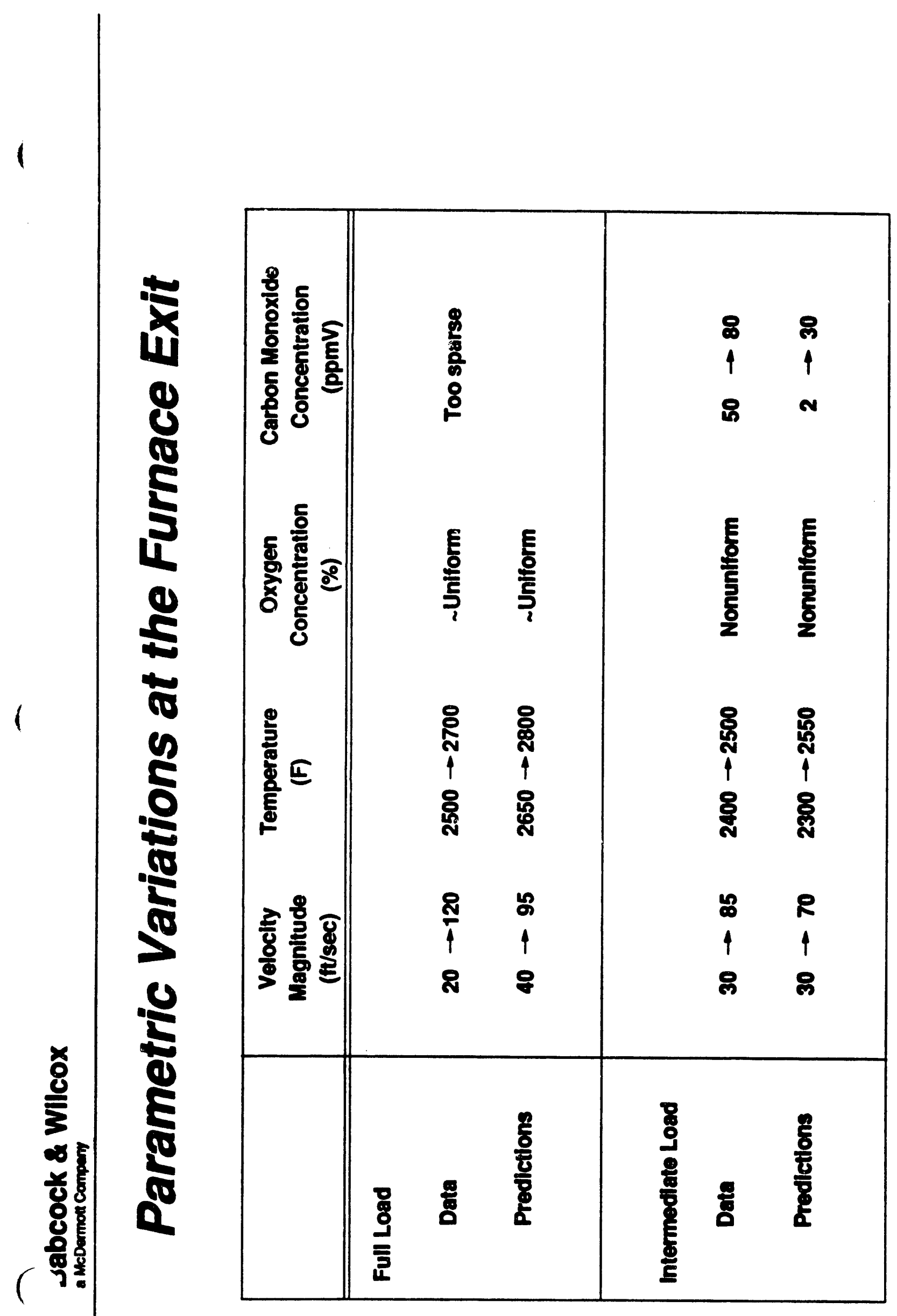


APPENDIX B 


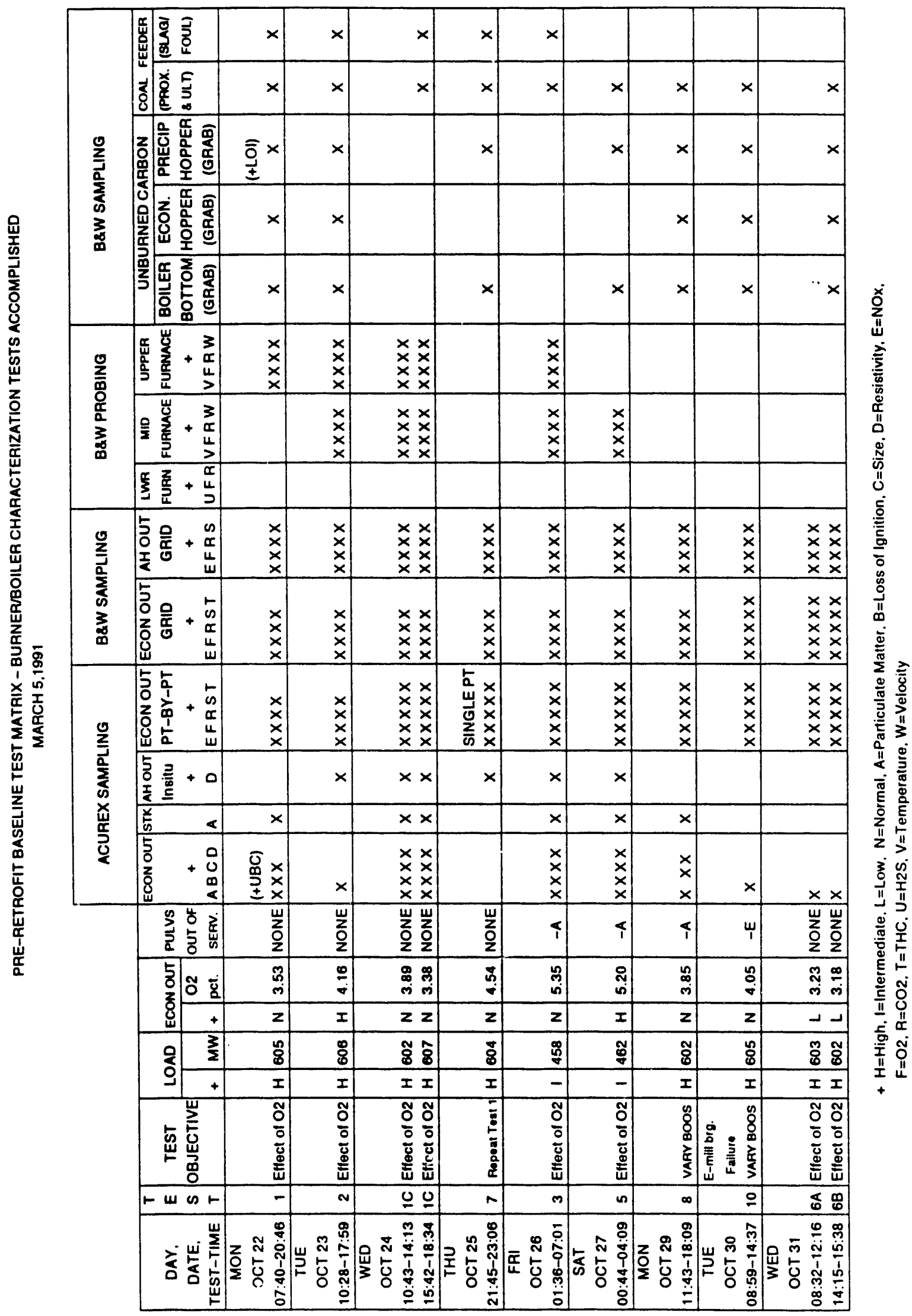




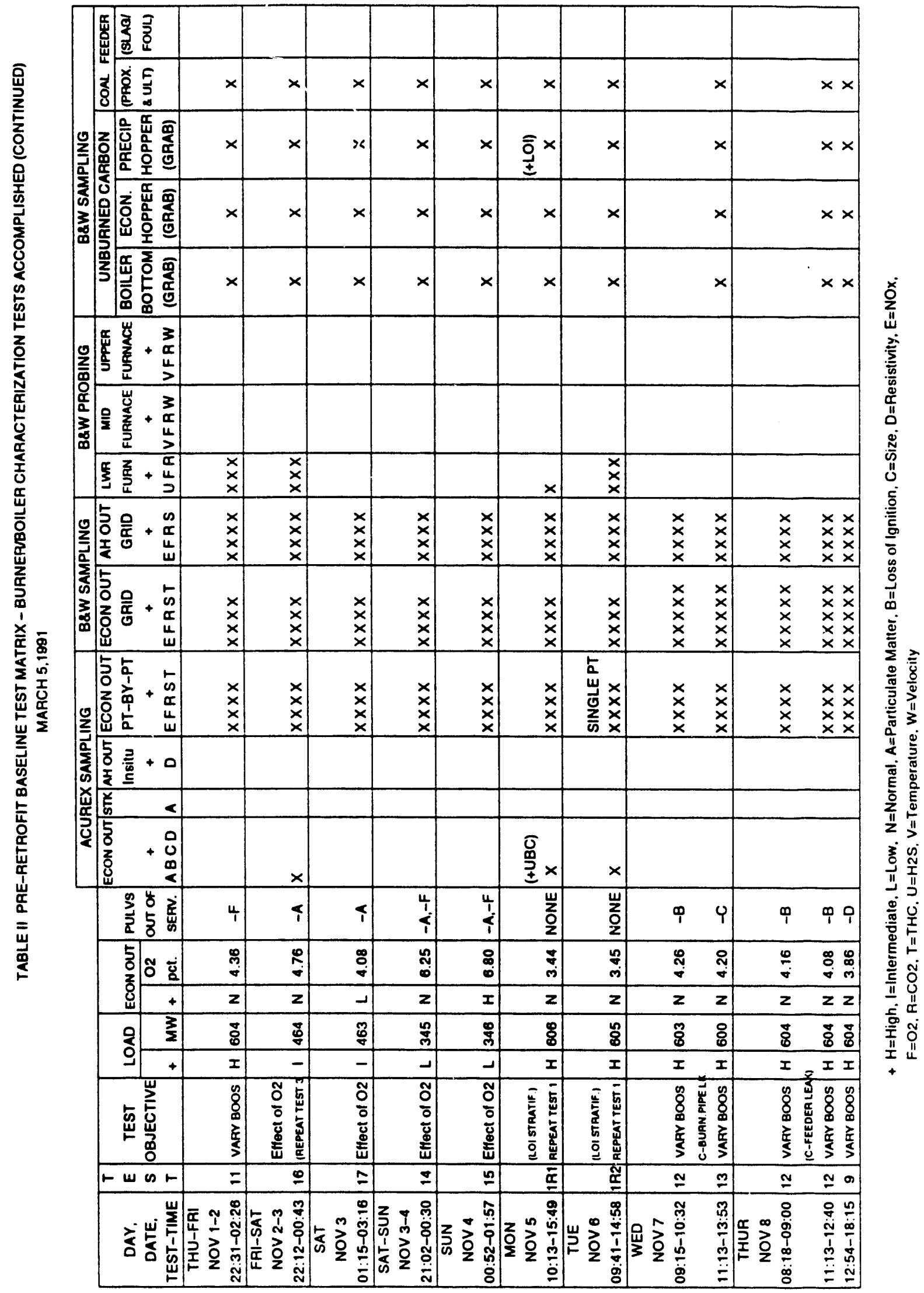




\title{
Clean Coal Technology III Project Full Scale Demonstration of Low NOx Cell Burner Baseline Testing
}

\author{
Data Acquisition
}

\section{Performance Monitoring}

\section{Gas Sampling Grids}

Boiler Gas Outlet - used a $\mathbf{4 0}$ point sampling grid in each gas outlet flue to measure $\mathrm{O}_{2}, \mathrm{CO}_{2}, \mathrm{CO}$ and Temperature.

Airheater Gas Outlet - used a 36 point sampling grid in each gas outlet flue to measure $\mathrm{O}_{2}, \mathrm{CO}_{2}, \mathrm{CO}, \mathrm{NOx}$ and temperature.

Sampling Technique - asperate samples from probes through averaging bubblers and ice bath conditioners.

Sensors -

$\mathrm{O}_{2}$ - Beckman 755 Thermomagnetic Analyzer $\mathrm{CO}_{2}$ - Beckman 864/865 Non-dispersive IR Analyzer $\mathrm{CO}$ - Same as $\mathrm{CO}_{2}$ NOx - Thermo Electron Chemiluminescence Temperature - Type K Thermocouples 


\section{Emissions Test Port Locations on Stuart Unit \#4}

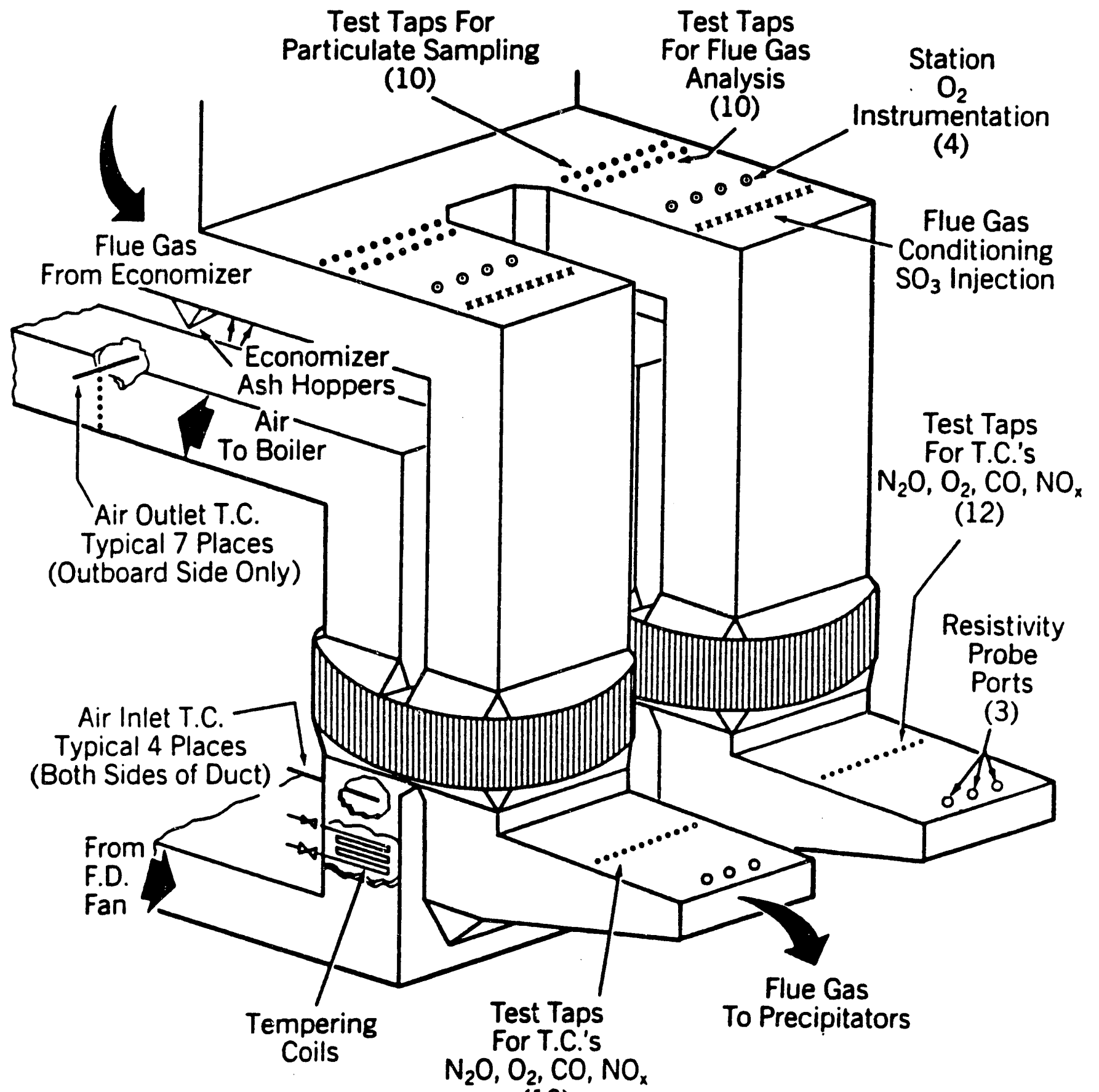

(12)

Babcock \& Wilcox a McDermolt company September 1990 


\section{Clean Coal Technology III Project Full Scale Demonstration of Low NOx Cell Burner Baseline Testing}

\section{Data Acquisition}

\section{Performance Monitoring}

Data Acquisition Computer HP - $9000 / 216$ Computer Interfaced to plant computer instrumentation.

Scanned on 1 minute intervals

Recorded pressures, temperatures, flows, electrical power, flue gas $\mathrm{O}_{2} \mathrm{~s}$

Interfaced to HP-3497 multiplexing DVM.

Scanned on 5 minute intervals

Recorded pressures, temperatures, flows, flue gas $\mathrm{O}_{2} \mathrm{~s}$, COs, $\mathrm{CO}_{2} \mathrm{~s}$.

Engineering unit conversions, range checking Archival Storage

Send input to Performance System Computer 


\section{Clean Coal Technology III Project Full Scale Demonstration of Low NOx Cell Burner Baseline Testing}

\section{Data Acquisition \\ Performance Monitoring}

Fuel - Ash Sampling

Barge Coal Samples

Each barge of coal used for test

Coal Feeder Samples

Each feeder in-service for each test

Samples composited for each test

Bottom Ash

Samples collected during each test

Economizer Ash

Samples collected during each test

Precipitator Ash

Samples collected during each test 


\section{Clean Coal Technology III Project Full Scale Demonstration of Low NOx Cell Burner Baseline Testing}

\section{Data Acquisition}

\section{Gaseous Emissions \& Particulate Sampling}

Boiler Gas Outlet

EPA Method 17

Particulates emissions

Continuous Emissions Monitoring

Used B\&W Test Grids

Sampled point - by - point, and 4 point composite

Measured, $\mathrm{NO}, \mathrm{NO}_{2}, \mathrm{CO}, \mathrm{CO}_{2}, \mathrm{O}_{2}$, and

Total Hydro Carbons

Boiler Gas Outlet

EPA Method 5

Particulates emissions 
Table 3-1. Continuous monitoring equipment in the Acurex mobile laboratory

\begin{tabular}{|c|c|c|c|c|}
\hline Instrument & $\begin{array}{l}\text { Principle of } \\
\text { Operation }\end{array}$ & Manufacturer & $\begin{array}{c}\text { Instrument } \\
\text { Model }\end{array}$ & Range \\
\hline $\begin{array}{l}\text { NO } \\
\text { NO }\end{array}$ & Chemiluminescence & Thermo Electron & $10 \mathrm{AR}$ & $\begin{array}{l}0 \text { to } 100 \mathrm{ppm} \\
0 \text { to } 500 \mathrm{ppm} \\
0 \text { to } 1,000 \mathrm{ppm} \\
0 \text { to } 5,000 \mathrm{ppm}\end{array}$ \\
\hline $\mathrm{CO}$ & $\begin{array}{l}\text { Nondispersive } \\
\text { infrared (NDIR) }\end{array}$ & ANARAD & SOOR & 0 to $1,000 \mathrm{ppm}$ \\
\hline $\mathrm{CO}_{2}$ & $\begin{array}{l}\text { Nondispersive } \\
\text { infrared (NDIR) }\end{array}$ & AṆARAD & AR500 & 0 to 20 percent \\
\hline $\mathrm{O}_{2}$ & Fuel cell & Teledyne & & $\begin{array}{l}0 \text { to } 5 \text { percent } \\
0 \text { to } 25 \text { percent }\end{array}$ \\
\hline $\begin{array}{l}\text { Total } \\
\text { hydrocarbon }\end{array}$ & $\begin{array}{l}\text { Flame ionization } \\
\text { Jetector (FID) }\end{array}$ & Beckman & 400 & $\begin{array}{l}0 \text { to } 1 \mathrm{ppm} \\
0 \text { to } 10 \mathrm{ppm} \\
0 \text { to } 100 \mathrm{ppm} \\
0 \text { to } 1,000 \mathrm{ppm} \\
0 \text { to } 10,000 \mathrm{ppm} \\
0 \text { to } 1 \text { percent } \\
0 \text { to } 2 \text { percent }\end{array}$ \\
\hline $\begin{array}{l}\text { Sample gas } \\
\text { conditioner }\end{array}$ & $\begin{array}{l}\text { Refrigerant } \\
\text { dryer-condenser }\end{array}$ & Hankinson & E-4G-SS & $10 \mathrm{scfm}$ \\
\hline $\begin{array}{l}\text { Strip chart } \\
\text { recorder }\end{array}$ & Dual-pen analog & Linear & 400 & $\begin{array}{l}0 \text { to } 10 \mathrm{mV} \\
0 \text { to } 100 \mathrm{mV} \\
0 \text { to } 1 \mathrm{~V} \\
0 \text { to } 10 \mathrm{~V}\end{array}$ \\
\hline Data logger & Electronic & Autodata/Acurex & 10 & $\begin{array}{l}99 \text { channels } \\
\text { programmable }\end{array}$ \\
\hline
\end{tabular}




\section{Clean Coal Technology III Project Full Scale Demonstration of Low NOx Cell Burner Baseline Testing}

\section{Data Acquisition}

\section{Experimental Techniques}

Furnace Probing

Lower Furnace (Bumer Zone)

Gas Temperature

$\mathrm{H}_{2} \mathrm{~S}$

Furnace Exit Plane

Gas Temperature

$\mathrm{O}_{2}, \mathrm{CO}, \mathrm{CO}_{2}$

Velocity

In-Situ Ash Resistivity

Airheater Inlet

Before $\mathrm{SO}_{3}$ injection ports

Airheater Outlet 
Table I - Ultimate Fuel Analysis

\begin{tabular}{|c|c|c|c|c|c|c|c|c|c|}
\hline Semple & $\begin{array}{l}\text { Hiohsur Heoting } \\
\text { Velue } \\
\text { Btu/lb }\end{array}$ & $\underset{* w .}{c}$ & $\begin{array}{c}H_{2} \\
x_{w t} .\end{array}$ & $\begin{array}{c}s \\
\times \mathrm{m} .\end{array}$ & $\underset{*}{\mathbf{O}_{2}}$ & $\boldsymbol{*}^{\mathrm{N}_{2}}$ w. & $\begin{array}{c}H_{2}, \mathrm{O} \\
\times \mathbf{w t} .\end{array}$ & $\underset{x w t .}{A c h}$ & $\begin{array}{l}\text { Theorotical } \\
\text { Air } \\
10 k \text { BTU }\end{array}$ \\
\hline 01 CM1 022902100 & 12041.0 & 67.42 & 4.03 & .95 & 7.67 & 1.22 & 4.55 & 13.60 & 7.510 \\
\hline $02 \mathrm{CM} 1023901800$ & 11957.0 & 66.99 & 4.54 & .90 & 7.25 & 1.41 & 5.02 & 13.89 & 7.805 \\
\hline $01 \mathrm{CM}_{1} 024902030$ & 11780.0 & 65.83 & 4.40 & 1.07 & 7.01 & 1.15 & 0.31 & 13.63 & 7.469 \\
\hline $01 \mathrm{CM} 1025902400$ & 11082.0 & 06.00 & 4.53 & 1.10 & 7.37 & 1.31 & 5.61 & 13.48 & 7.462 \\
\hline $03 \mathrm{CM} 1026900740$ & 11839.0 & 65.95 & 4.48 & 1.12 & 7.01 & 1.16 & 5.39 & 13.90 & 7.445 \\
\hline $05 \mathrm{CAN}_{1027900410}$ & 11888.0 & 60.01 & 4.47 & 1.14 & 7.32 & 1.15 & 5.47 & 13.24 & 7.498 \\
\hline DeCM1 029901800 & 11500.0 & 64.87 & 4.41 & 1.17 & 7.32 & 1.25 & 5.78 & 15.20 & 7.520 \\
\hline $10 \mathrm{CM} 1030901530$ & 11730.0 & 85.46 & 4.42 & .96 & 7.12 & 1.23 & 5.72 & 15.09 & 7.472 \\
\hline $08 \mathrm{CM} 1031901530$ & 12000.0 & 67.56 & 4.57 & 1.02 & 7.30 & 1.28 & 5.05 & 13.22 & 7.507 \\
\hline $11 \mathrm{CM} 1102900230$ & 11770.0 & 65.75 & 4.38 & 1.15 & 7.06 & 1.11 & 5.81 & 14.13 & 7.453 \\
\hline $18 \mathrm{CM} 1103900100$ & 11764.0 & 65.75 & 4.49 & 1.08 & 7.02 & 1.01 & 4.92 & 15.13 & 7.485 \\
\hline $17 \mathrm{CM} 1103900230$ & 11018.0 & 64.68 & 4.49 & 1.01 & 8.03 & 1.17 & 0.04 & 14.60 & 7.453 \\
\hline $14 \mathrm{CM} 1103902300$ & 11894.0 & 66.38 & 4.55 & 1.03 & 7.77 & 1.29 & 4.71 & 14.26 & 7.475 \\
\hline $15 \mathrm{CM} 1104900100$ & 11908.0 & 60.15 & 4.55 & 1.44 & 7.57 & 1.24 & 4.77 & 14.28 & 7.460 \\
\hline $01 \mathrm{CM} 1105801800$ & 11786.0 & 64.93 & 4.57 & 1.11 & 8.05 & 1.11 & 4.87 & 15.36 & 7.399 \\
\hline 01 CM1108901430 & 11849.0 & 68.29 & 4.64 & 1.05 & 7.46 & 1.31 & 5.07 & 14.18 & 7.532 \\
\hline $13 \mathrm{CM} 1107901630$ & 11898.0 & 65.83 & 4.58 & 1.07 & 8.07 & 1.21 & 4.45 & 14.79 & 7.418 \\
\hline $12 \mathrm{CM} 1108901300$ & 11986.0 & 66.59 & 4.60 & 1.02 & 7.68 & 1.41 & 4.81 & 13.89 & 7.467 \\
\hline O9CM1108901730 & 12306.0 & 68.54 & 4.71 & 1.15 & 8.20 & 1.03 & 4.57 & 11.80 & 7.424 \\
\hline
\end{tabular}


Table III - Onburned Carbon

\begin{tabular}{|c|c|c|c|c|}
\hline \multirow{3}{*}{$\begin{array}{c}\text { Toot } \\
10\end{array}$} & \multicolumn{3}{|c|}{$\begin{array}{c}\text { Cerbon in Rofues } \\
\text { by BaW }\end{array}$} & \multirow{2}{*}{$\begin{array}{c}\text { Cerbon in } \\
\text { Flus Dust } \\
\text { by } \\
\text { Acurex }\end{array}$} \\
\hline & $\begin{array}{c}\text { Bottom } \\
\text { Aeh }\end{array}$ & $\begin{array}{l}\text { Econ } \\
\text { Hopoer }\end{array}$ & $\begin{array}{l}\text { Precip } \\
\text { Hopper }\end{array}$ & \\
\hline & $x w t$ & $\% w t$ & $x w t$ & $x w$ \\
\hline 1 & 1.72 & 3.37 & 2.53 & 1.31 \\
\hline ICA & 7.63 & & 1.60 & 0.77 \\
\hline 108 & 7.63 & & 1.60 & \\
\hline \multicolumn{5}{|l|}{7} \\
\hline IR1 & 1.74 & 7.13 & 1.81 & 1.14 \\
\hline IR2 & 0.89 & 4.77 & 1.14 & 0.86 \\
\hline 2 & 4.21 & 4.97 & 2.48 & 1.46 \\
\hline $6 A$ & 4.67 & 7.22 & 1.06 & \\
\hline 68 & 4.67 & 7.22 & 1.05 & \\
\hline 8 & 4.42 & 7.34 & 1.82 & \\
\hline $12 A$ & 2.40 & 5.99 & & \\
\hline 128 & 1.06 & 6.39 & 1.56 & \\
\hline $12 \mathrm{C}$ & 1.06 & 5.39 & 1.56 & \\
\hline 13 & 2.04 & 3.56 & 2.17 & \\
\hline 9 & 1.87 & 11.57 & 3.02 & \\
\hline 10 & 2.22 & 6.98 & 1.84 & 1.19 \\
\hline 11 & 4.10 & 5.40 & 1.84 & \\
\hline 3 & & & & 1.20 \\
\hline 16 & 4.58 & 11.80 & 1.86 & \\
\hline 5 & 10.40 & & 1.81 & 1.09 \\
\hline 17 & 5.58 & 13.64 & $0 . \bullet 0$ & \\
\hline 14 & 7.12 & 14.11 & 1.27 & \\
\hline 15 & 7.34 & 22.69 & 0.82 & \\
\hline
\end{tabular}


Table II - Efficiency

\begin{tabular}{|c|c|c|c|c|}
\hline & $\begin{array}{l}\text { Efticiency } \\
\text { a Tented }\end{array}$ & $\begin{array}{l}\text { Effleioncy } \\
\text { Comeeted } \\
\text { to Bese }\end{array}$ & Output & Excese Air \\
\hline 10 & \% & \% & $\underset{\substack{10^{\circ} \\
\mathrm{Br}}}{\mathrm{BTU}}$ & $\%$ \\
\hline 1 & 80.47 & 09.37 & 4822.8 & 19.8 \\
\hline ICA & 89.48 & 00.39 & 4833.1 & 22.3 \\
\hline $1 \mathrm{CB}$ & 89.71 & 80.42 & 4822.1 & 18.7 \\
\hline 7 & 80.67 & 0.66 & 4004.6 & 27.0 \\
\hline IAI & 89.50 & 89.28 & 4840.0 & 10.1 \\
\hline IA2 & 89.49 & 89.34 & 4846.4 & 18.2 \\
\hline 2 & 89.37 & 80.43 & 4821.6 & 24.1 \\
\hline $6 \mathrm{~A}$ & 89.79 & 80.56 & 4818.4 & 17.7 \\
\hline 68 & 89.86 & 80.43 & 4827.5 & 17.4 \\
\hline 8 & 89.66 & 80.51 & 4795.6 & 22.0 \\
\hline $12 A$ & 89.68 & 89.55 & 4813.7 & 24.9 \\
\hline $12 B$ & 09.89 & 89.77 & 4808.0 & 24.2 \\
\hline $12 \mathrm{C}$ & 89.96 & 89.75 & 4803.4 & 23.5 \\
\hline 13 & 89.72 & 89.50 & 4853.7 & 24.4 \\
\hline 8 & 90.08 & 89.72 & 4822.7 & 22.0 \\
\hline 10 & 89.80 & 89.72 & 4817.5 & 23.3 \\
\hline 11 & 89.80 & 89.67 & 4816.3 & 25.6 \\
\hline 3 & 89.79 & 80.95 & 3731.1 & 33.4 \\
\hline 16 & 89.76 & 09.83 & 3730.3 & 28.6 \\
\hline 5 & 89.71 & 69.88 & 3747.7 & 32.2 \\
\hline 17 & 89.67 & 09.87 & 3730.4 & 23.6 \\
\hline 14 & 90.12 & $\infty 0.44$ & 2887.0 & 41.5 \\
\hline 15 & $\infty 0.23$ & 0.61 & 2075.9 & 46.9 \\
\hline
\end{tabular}


Table IV - NOx Emissions

\begin{tabular}{|c|c|c|c|c|c|c|c|c|c|c|c|c|}
\hline \multirow{3}{*}{$\begin{array}{l}\text { Teet } \\
10\end{array}$} & \multicolumn{4}{|c|}{$\begin{array}{l}\text { Fluo Ges Leevino } \\
\text { Eeconomizer }\end{array}$} & \multirow{2}{*}{\multicolumn{2}{|c|}{$\begin{array}{c}\text { Flue Ges Leoving } \\
\text { SAH }\end{array}$}} & \multicolumn{4}{|c|}{ NOx Concentretion (pom) } & \multicolumn{2}{|c|}{ NOx Eminaion } \\
\hline & \multicolumn{2}{|c|}{ Acurax } & \multicolumn{2}{|c|}{ sew } & & & \multicolumn{2}{|c|}{ Aevrex } & \multicolumn{2}{|c|}{ Baw } & \multirow{2}{*}{$\begin{array}{l}\text { Aarex } \\
\text { Leo per } \\
10^{\circ} \text { Beu }\end{array}$} & \multirow{2}{*}{$\frac{\text { Bew }}{10^{\circ} \text { Btu }}$} \\
\hline & $\begin{array}{c}\text { Excen } \\
0, \%\end{array}$ & Nexpen & $\underset{0, \pi}{\operatorname{Excen}}$ & $\begin{array}{l}\text { Excen } \\
\text { Nir } \%\end{array}$ & Excen & Ancon & $\begin{array}{l}\text { Mew. } \\
\text { Leaving } \\
\text { Eeen }\end{array}$ & $\begin{array}{l}\text { Cerr. to } \\
3 \% O_{2}\end{array}$ & $\begin{array}{l}\text { Meas. } \\
\text { Leoving } \\
\text { SAY }\end{array}$ & $\begin{array}{l}\text { Cerr. to } \\
3 \times 0,\end{array}$ & & \\
\hline 1 & 3.330 & 18.3 & 3.634 & 10.7 & 4.886 & 20.3 & 003.0 & 970.2 & 760.1 & 080.0 & 1.201 & 1.172 \\
\hline ICA & 3.406 & 10.4 & 3.801 & 22.2 & 6.277 & 32.0 & 000.0 & อes.7 & 762.2 & 801.0 & 1.210 & 1.170 \\
\hline $1 \mathrm{CB}$ & 3.406 & 10.4 & 3.378 & 18.7 & 4.048 & 27.7 & өеe.0 & อes.7 & 785.0 & 843.3 & 1.210 & 1.151 \\
\hline 7 & 3.700 & 20.8 & 4.042 & 20.0 & 4.043 & 28.7 & 800.0 & 934.6 & 608.7 & 000.3 & 1.200 & 1.207 \\
\hline IRI & $\mathbf{3 . 0 7 0}$ & 20.6 & 3.441 & 10.1 & 4.730 & 28.4 & 808.0 & 037.3 & 731.4 & 10.1 & 1.120 & 1.001 \\
\hline 1R2 & 4.265 & 24.7 & 3.452 & 10.2 & 4.630 & 20.2 & 086.0 & 056.0 & 762.0 & 830.1 & 1.310 & 1.160 \\
\hline 2 & 4.100 & 24.3 & 4.167 & 24.1 & 6.400 & 34.8 & 183.0 & 024.6 & 700.0 & 200.1 & 1.283 & 1.238 \\
\hline $6 A$ & 3.080 & 16.7 & 3.226 & 17.7 & 4.614 & 27.6 & 821.6 & $\mathbf{2 5 . 2}$ & 723.0 & 704.6 & 1.128 & 1.086 \\
\hline $6 \mathrm{~B}$ & 3.074 & 16.7 & 3.178 & 17.4 & 4.734 & 28.4 & 0.0 & 0.0 & 713.1 & 700.8 & 0.000 & 1.070 \\
\hline 8 & 3.805 & 22.2 & 3.864 & 21.0 & 6.373 & 33.6 & 782.0 & 701.0 & 023.1 & 710.3 & 1.080 & .086 \\
\hline $12 A$ & 4.930 & 20.8 & 4.250 & 24.0 & 5.712 & 38.4 & 781.0 & 076.4 & 021.7 & 816.2 & 1.100 & 1.108 \\
\hline 128 & 3.820 & 21.7 & 4.101 & 24.1 & 6.168 & 31.7 & 002.0 & 124.3 & 500.0 & 681.1 & 1.256 & .028 \\
\hline $12 \mathrm{C}$ & 3.820 & 21.7 & 4.077 & 23.6 & 8.164 & 31.7 & 882.0 & 024.3 & 640.3 & 738.1 & 1.256 & 1.003 \\
\hline 13 & 4.460 & 26.2 & 4.190 & 24.3 & 5.674 & 30.1 & 822.0 & 010.2 & 787.0 & 226.0 & 1.236 & 1.240 \\
\hline 0 & 3.076 & 22.7 & 3.860 & 21.0 & 5.142 & 31.0 & 106.0 & 246.6 & 722.3 & 8205 & 1.278 & 1.108 \\
\hline 10 & 3.000 & 22.2 & 4.040 & 23.3 & 6.438 & 24.1 & 704.0 & 025.6 & 801.4 & 708.7 & 1.126 & 1.076 \\
\hline 11 & 4.340 & 26.4 & 4.365 & 25.6 & 5.605 & 35.2 & 722.0 & 720.4 & 010.2 & 712.3 & 1.082 & .000 \\
\hline 3 & 4.785 & 28.6 & 6.348 & 33.3 & 6.034 & 30.3 & 021.6 & 800.6 & 654.6 & 687.6 & .036 & .006 \\
\hline 16 & 4.380 & 26.7 & 4.767 & 28.6 & 0.002 & 30.0 & 044.0 & 807.8 & 661.0 & 074.1 & .051 & .010 \\
\hline 5 & 4.860 & 20.2 & 6.201 & 32.1 & 6.436 & 43.1 & 046.0 & 710.3 & 680.0 & 728.4 & .083 & .005 \\
\hline 17 & 4.710 & 28.2 & 4.081 & 23.6 & 6.022 & 36.7 & 068.0 & 726.3 & 842.3 & 035.4 & .087 & .884 \\
\hline 14 & 0.670 & 46.4 & 6.240 & 41.3 & 7.260 & 61.7 & 408.0 & 026.4 & 377.3 & 405.4 & .062 & .674 \\
\hline 16 & 7.000 & 65.3 & 6.003 & 46.7 & 7.052 & 58.3 & 42.0 & 720.6 & 302.0 & 537.8 & .001 & .731 \\
\hline
\end{tabular}




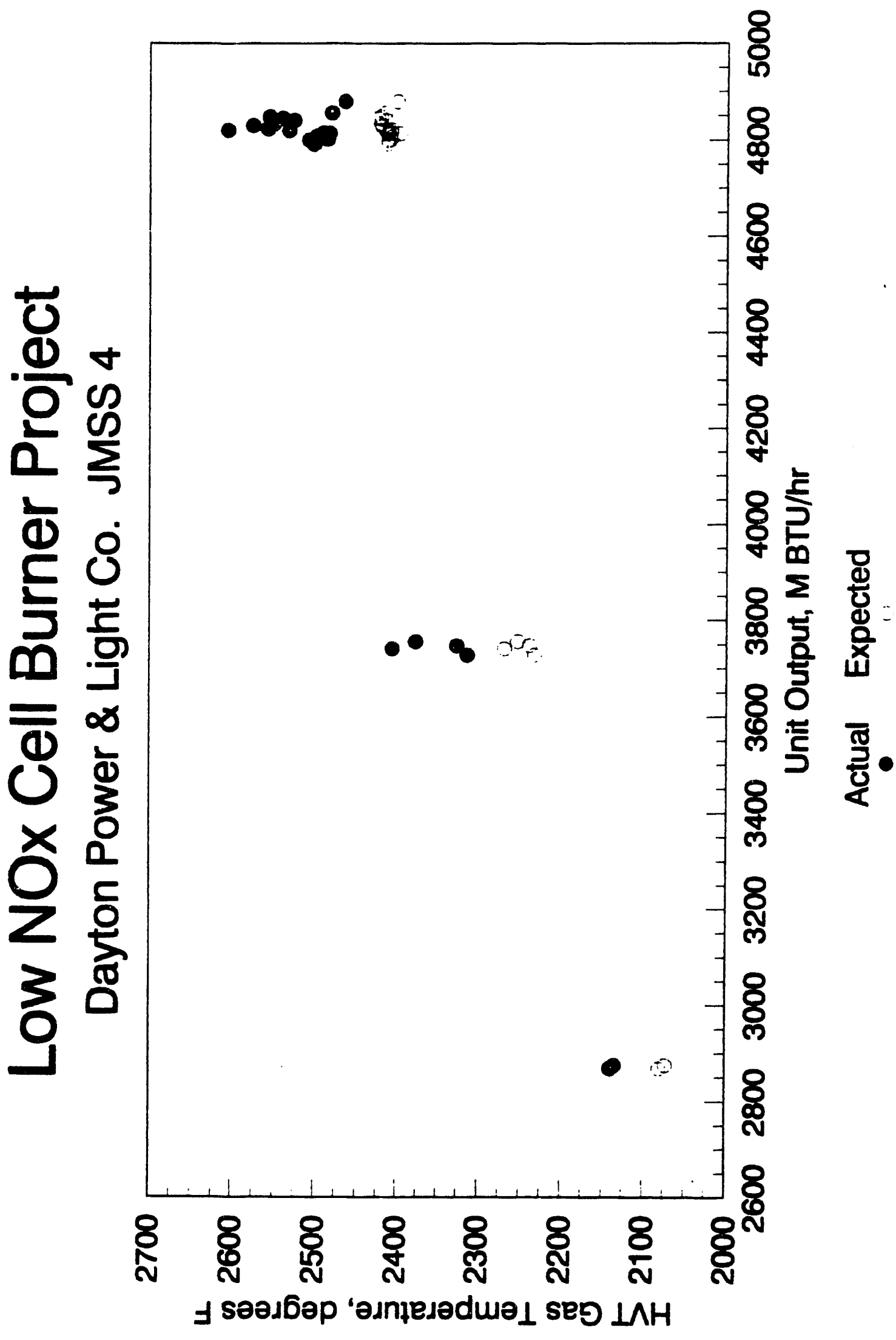

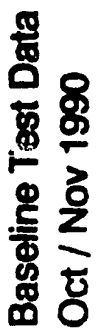




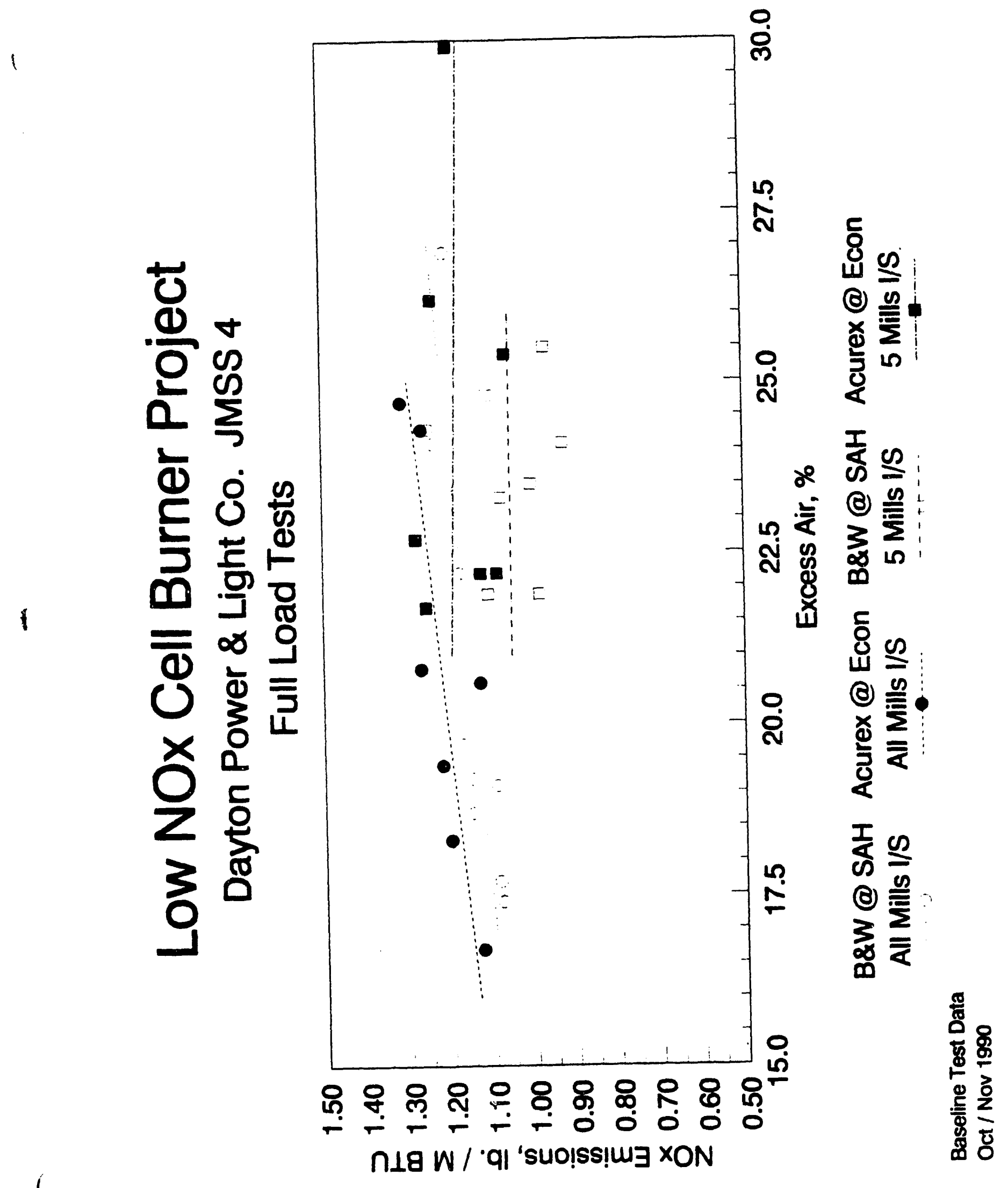




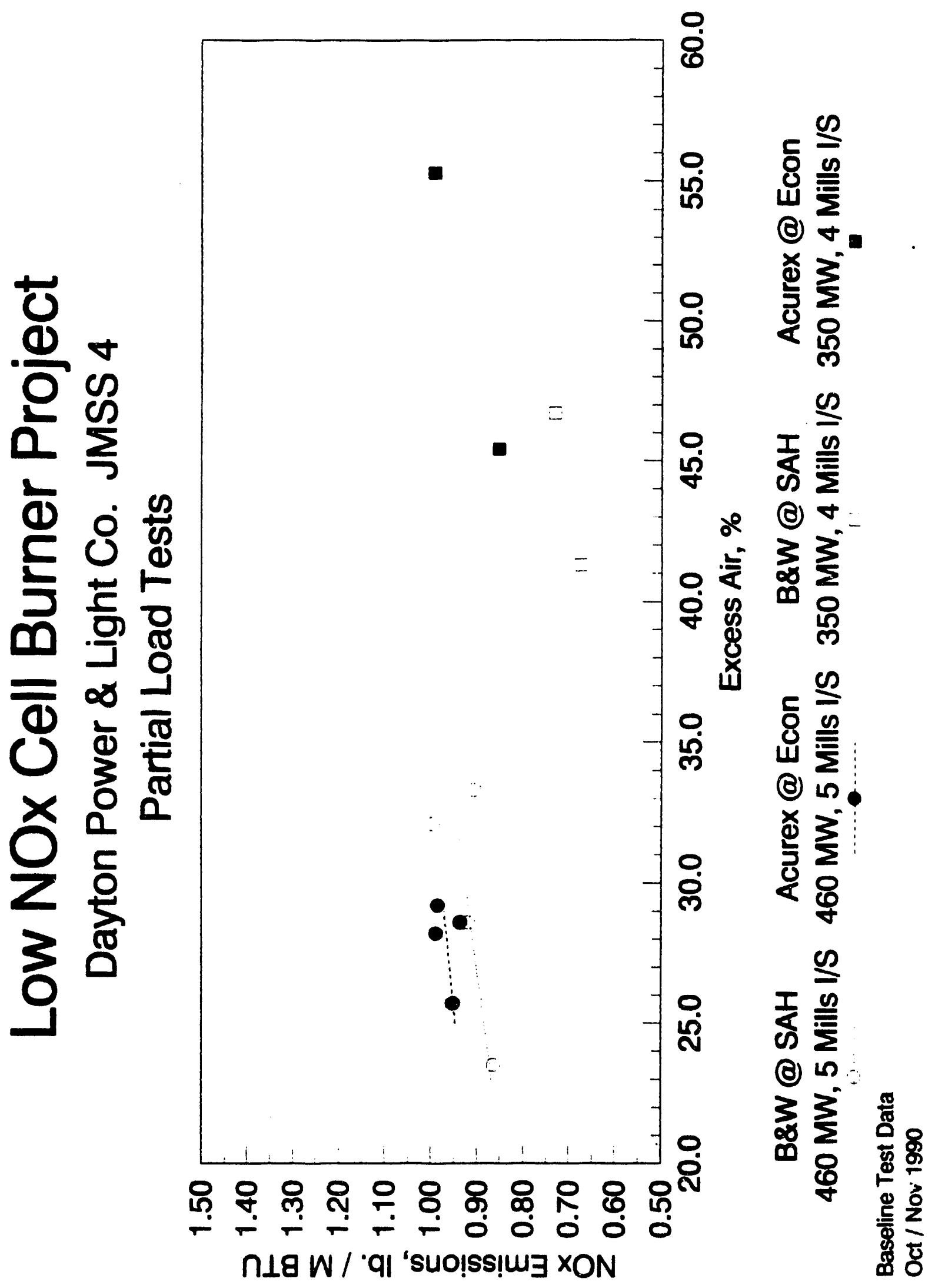




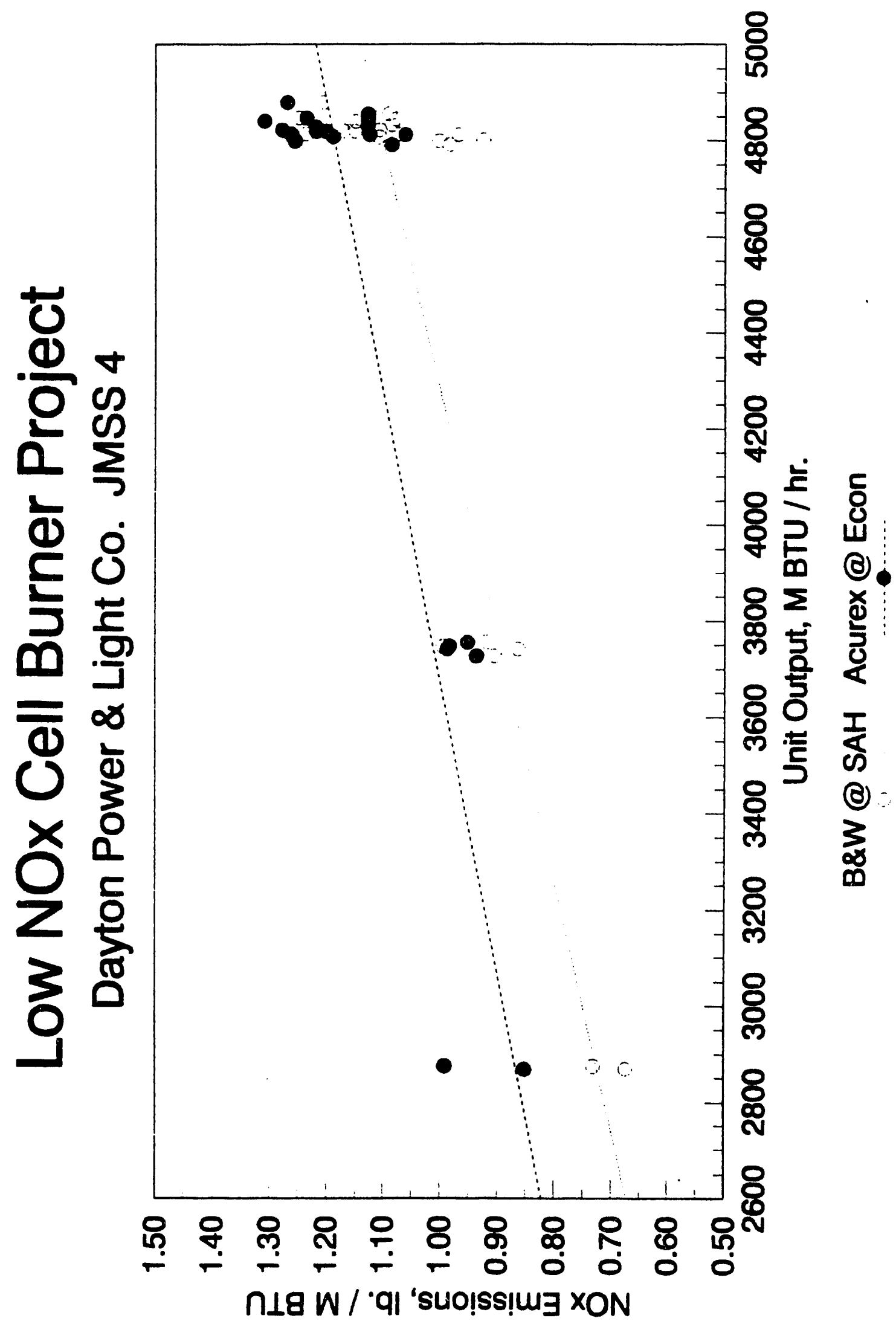

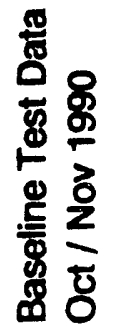




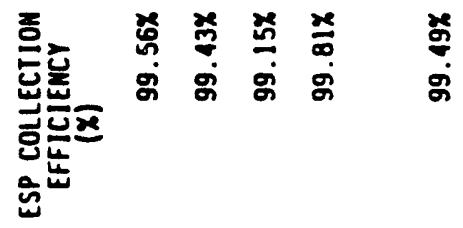

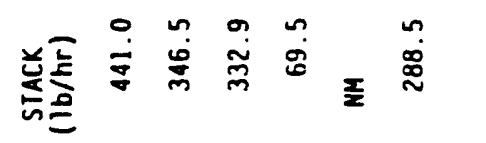

志

空言

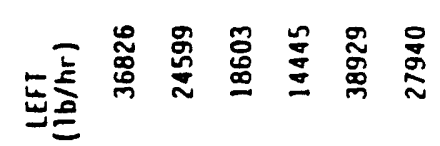

$\frac{3}{x}$

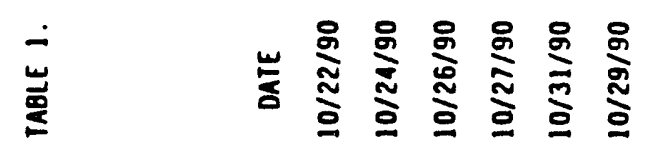

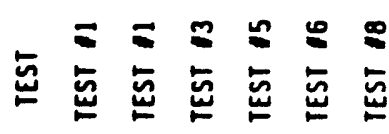




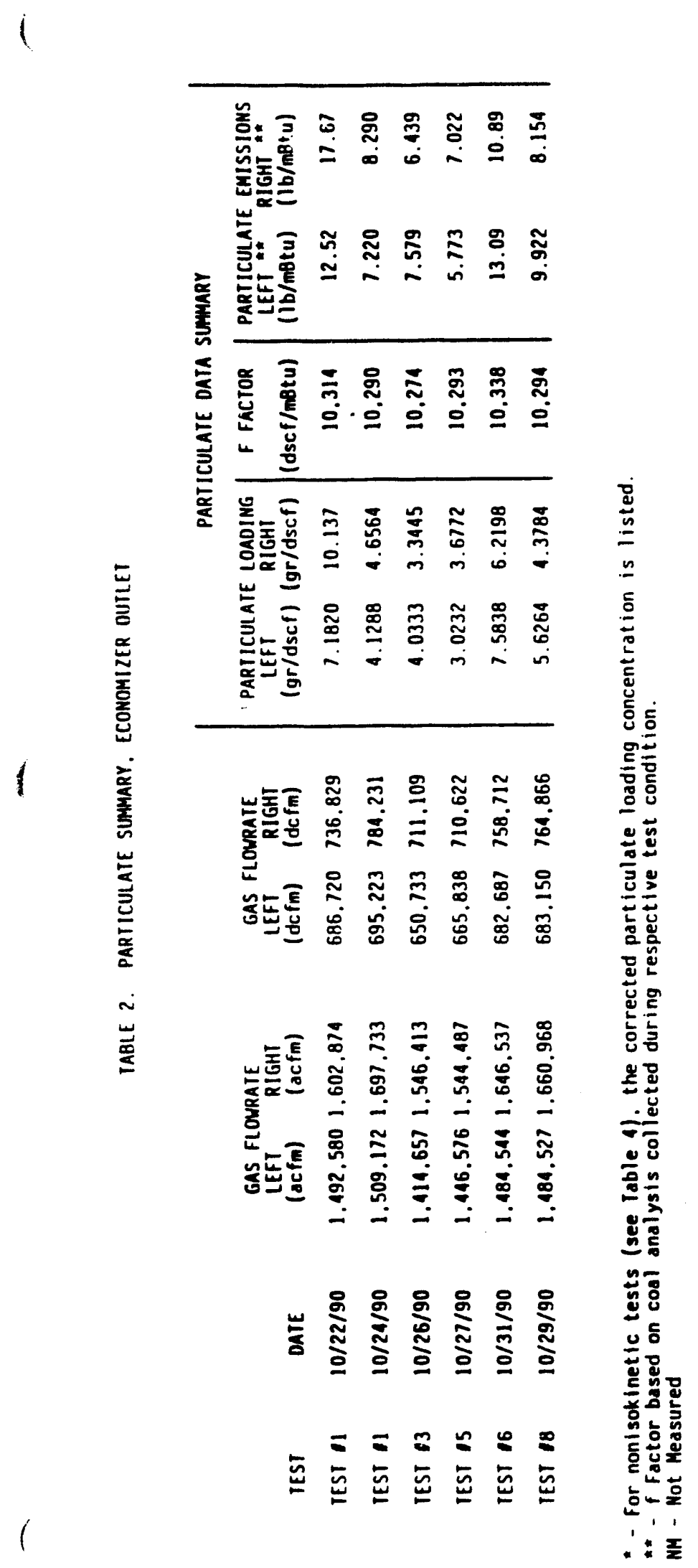




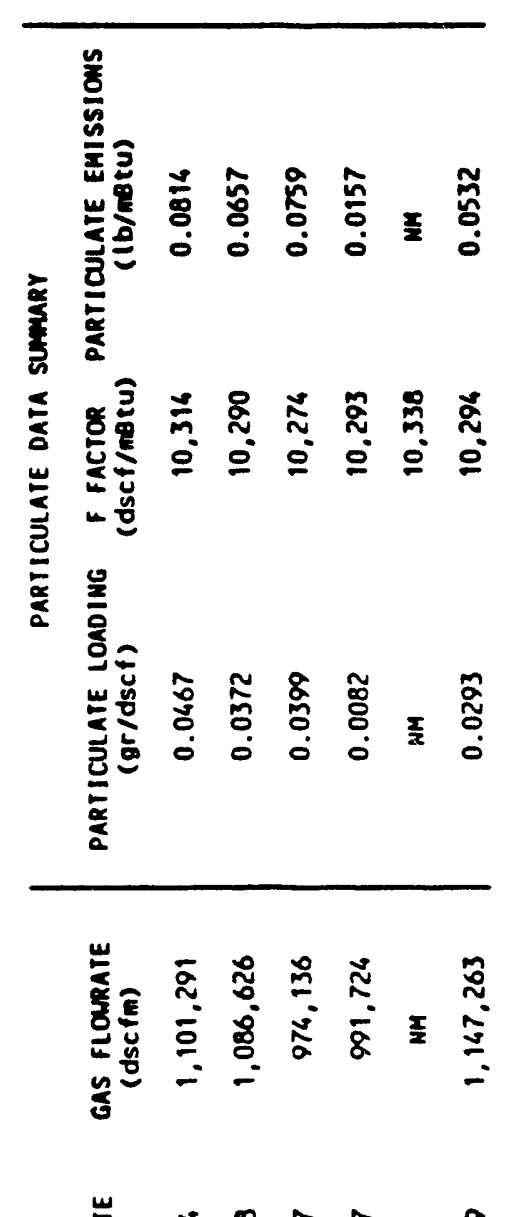

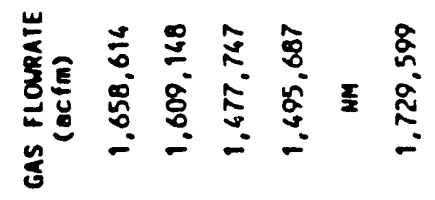

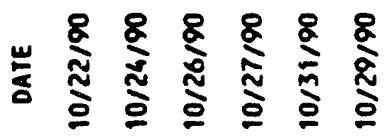

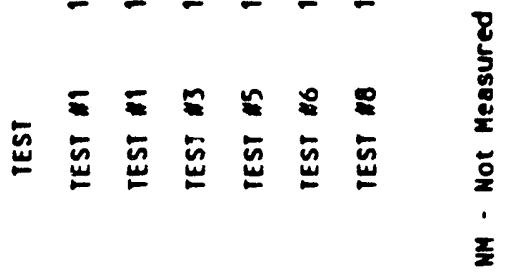


TABLE 1. BASELINE NOX TESTS -- STUART UNIT 4 LOSS ON IGNITION (LOI) SUMMARY

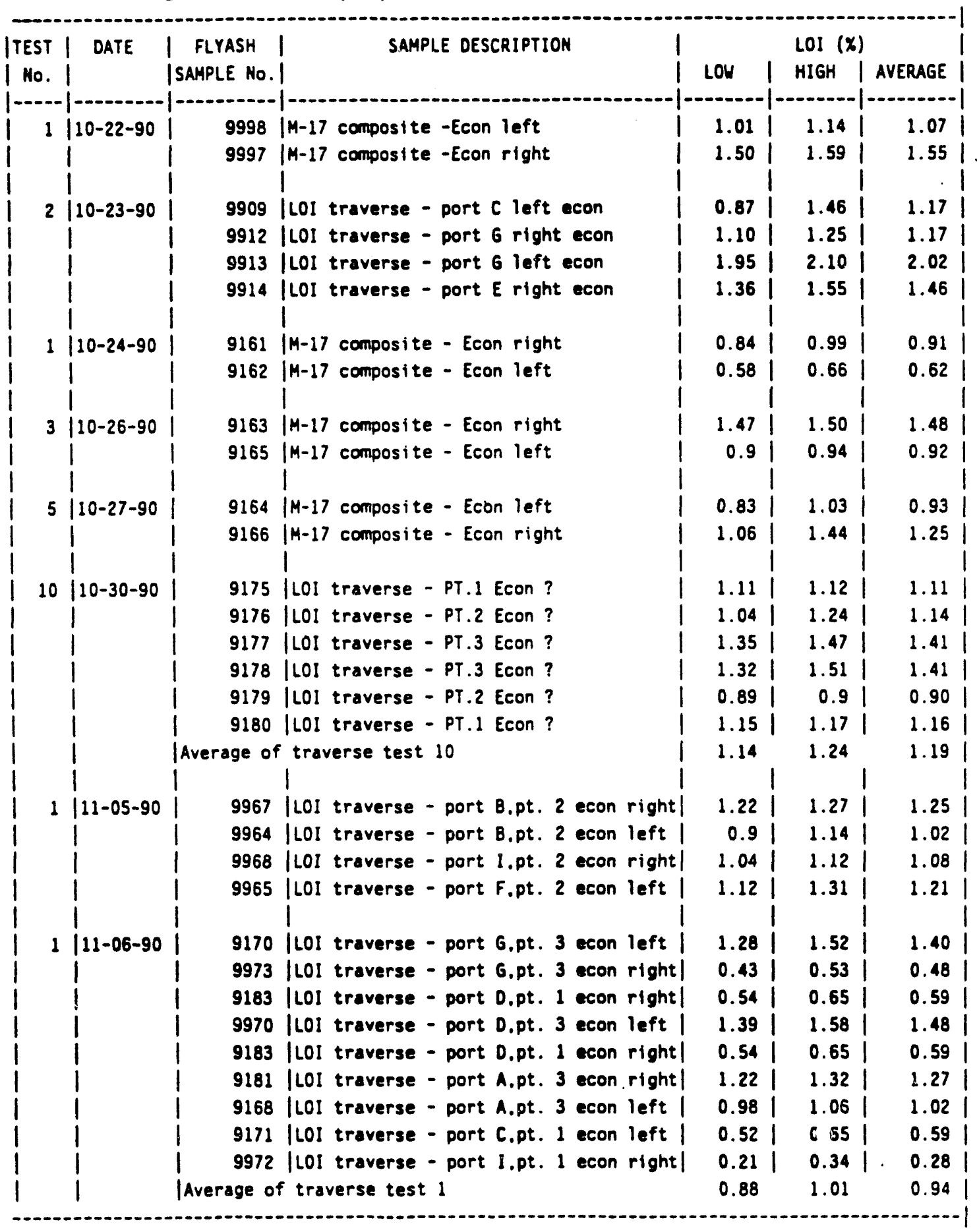




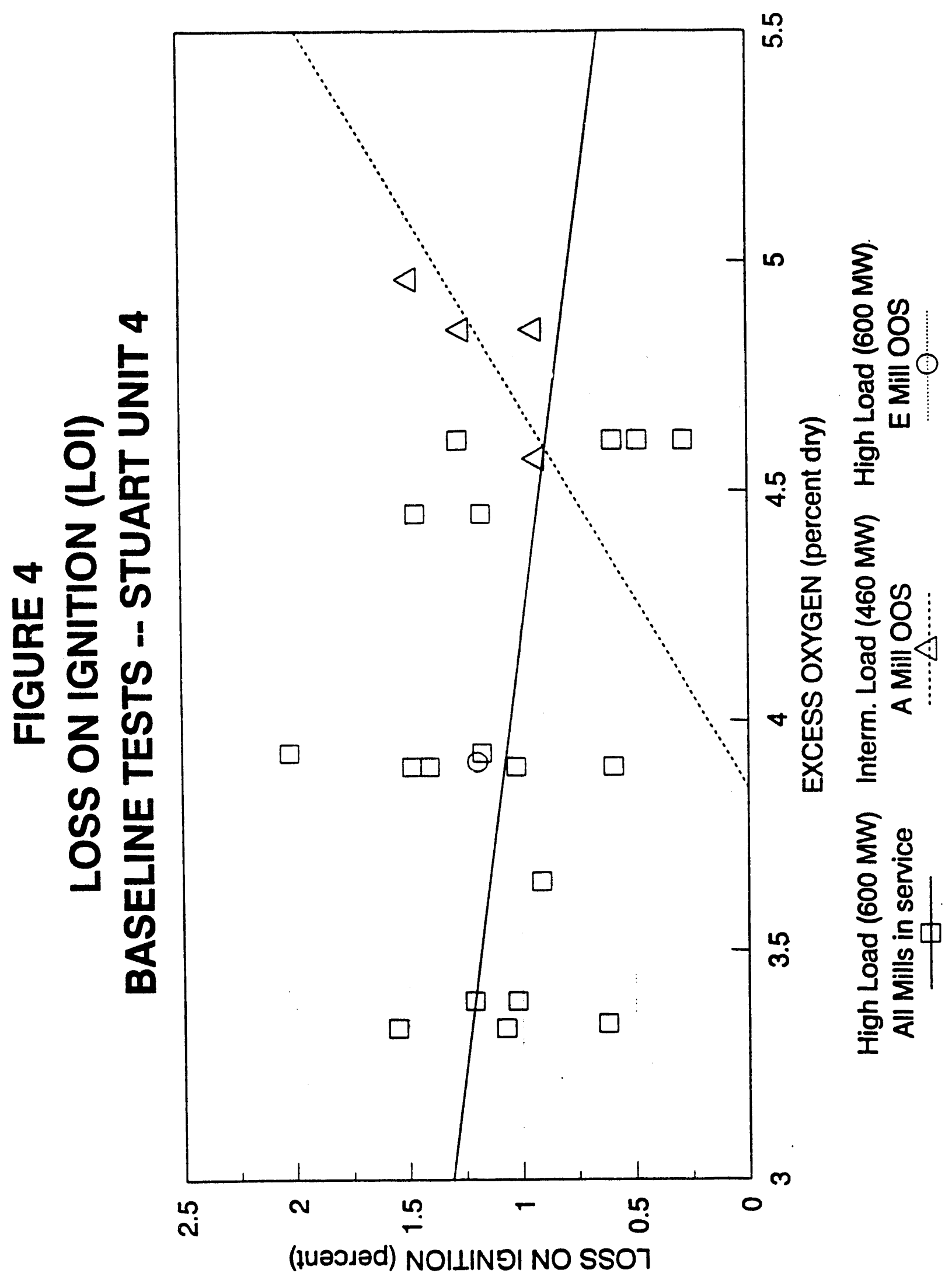




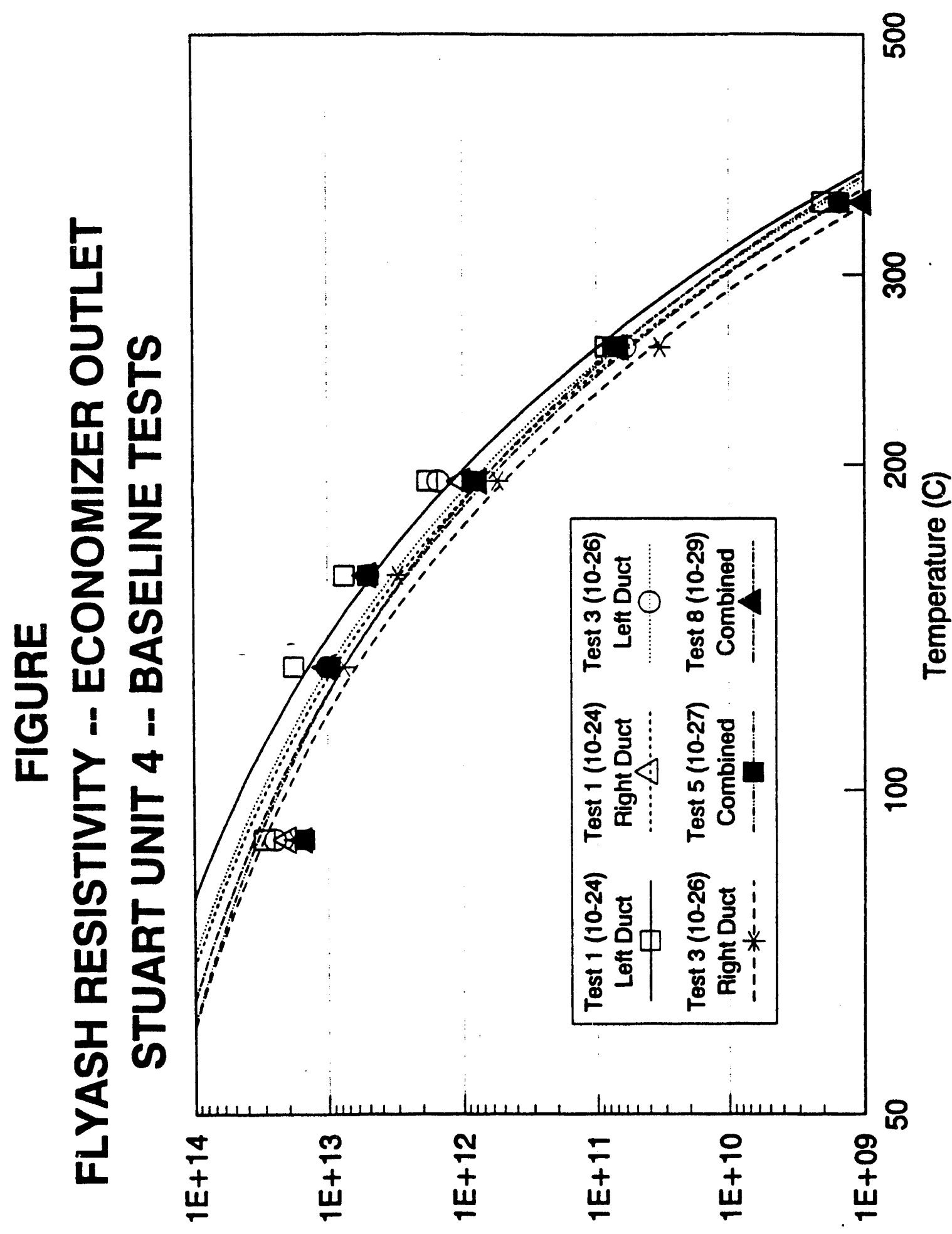

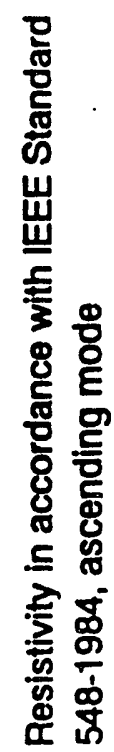




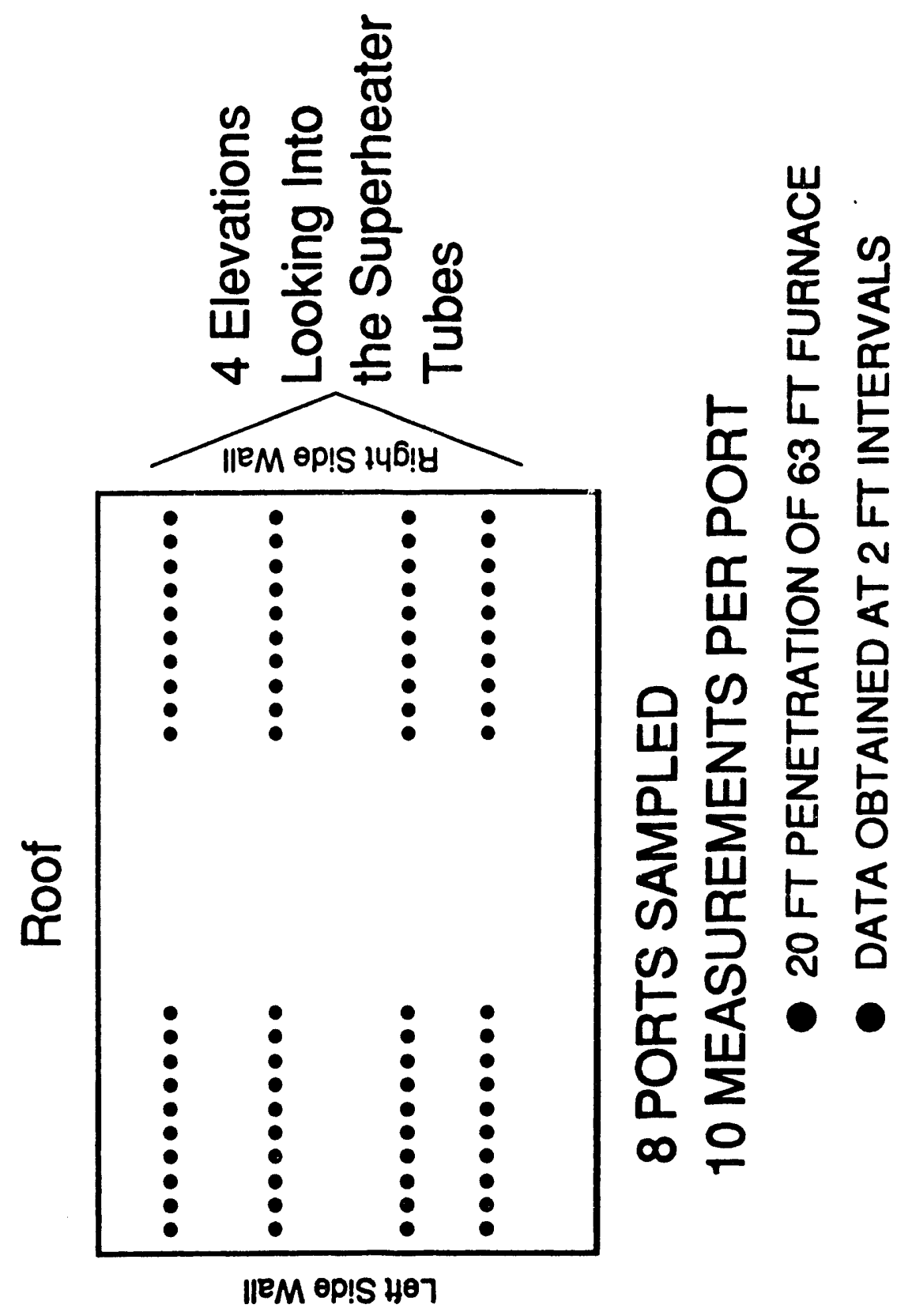

3

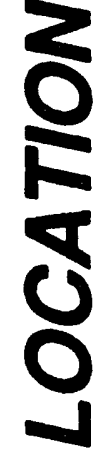

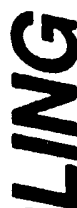

a

$\frac{1}{2}$

$\frac{11}{15}$

M

$\therefore 8$

흔

$+\pi N$ 


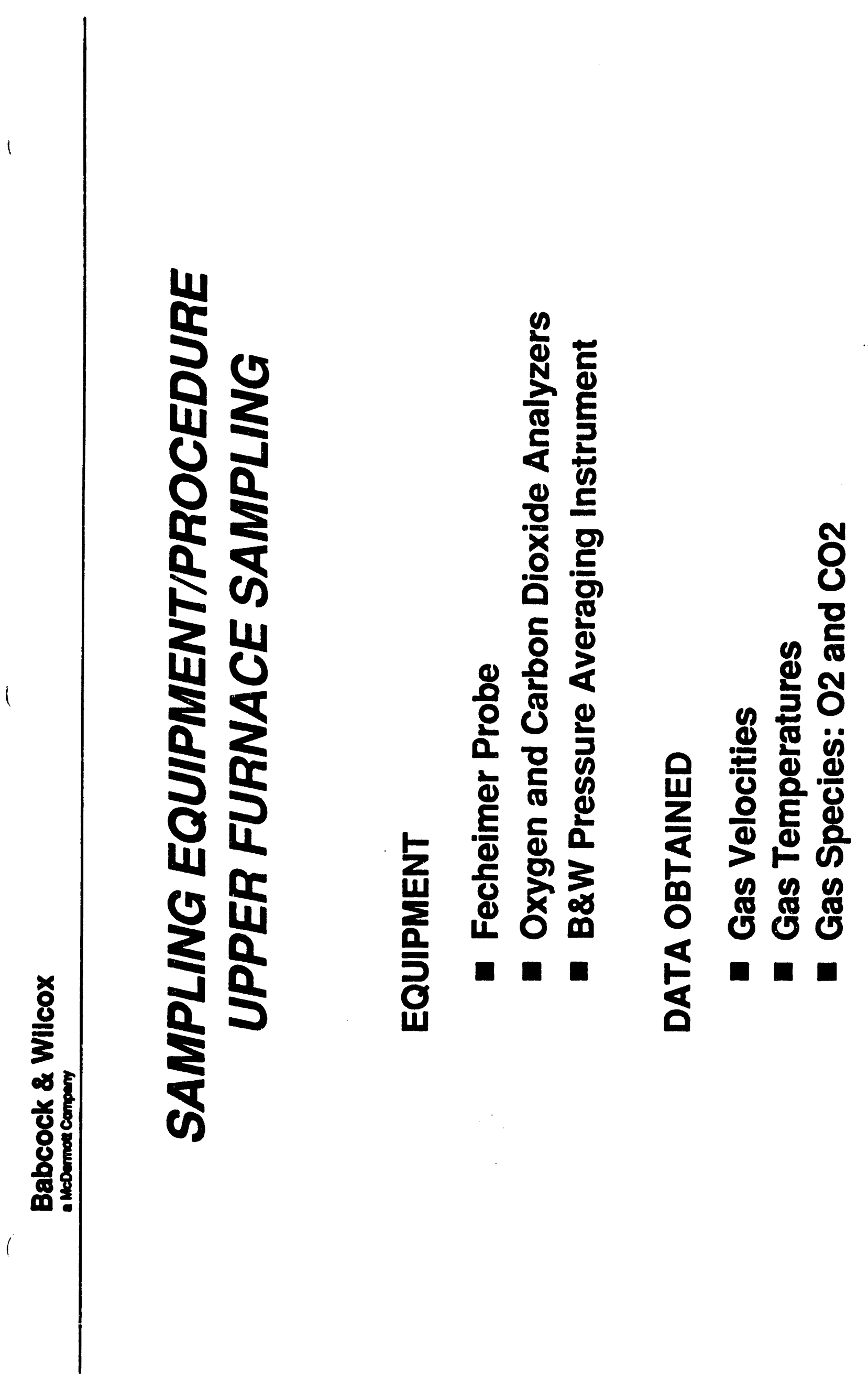




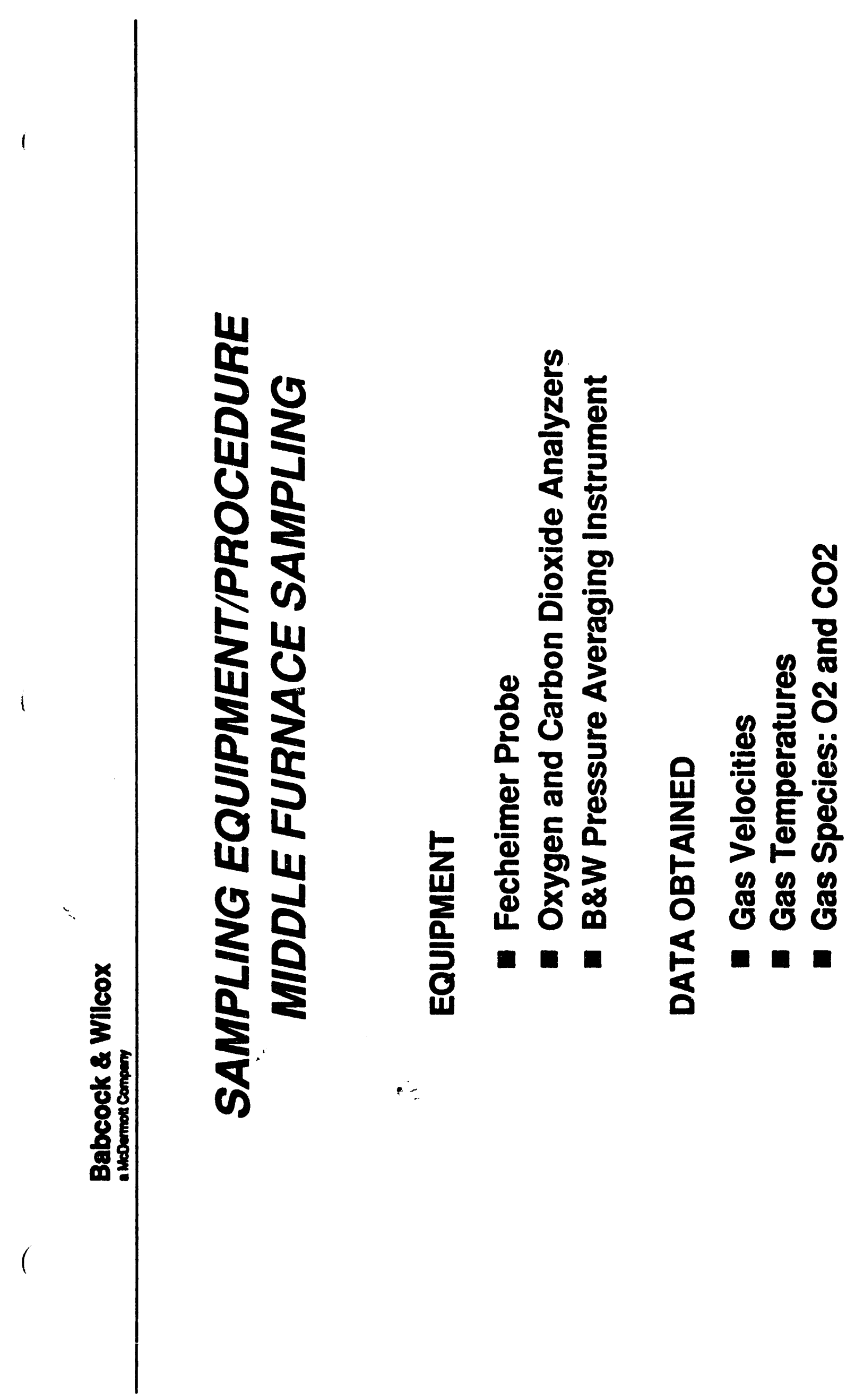




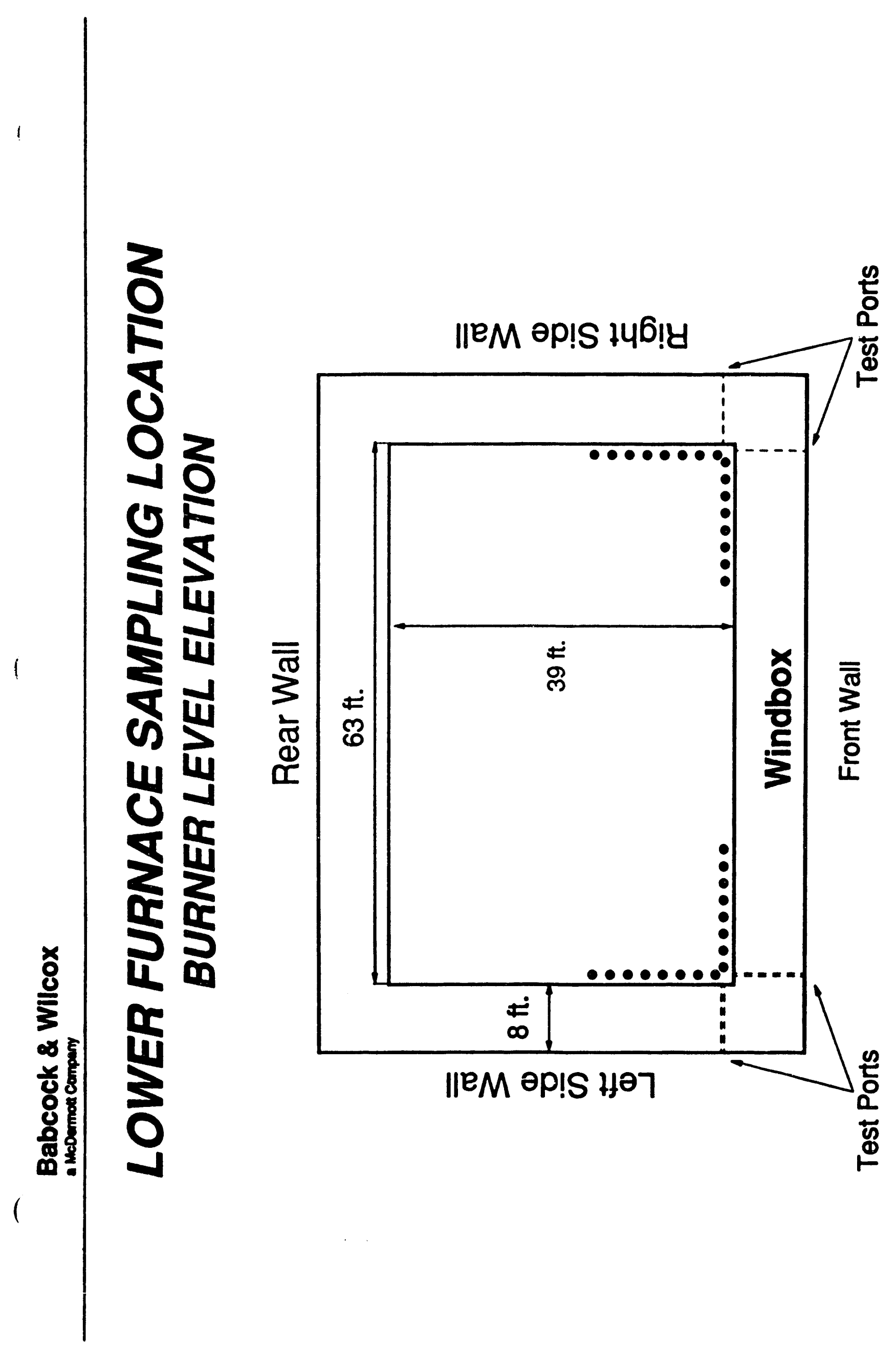




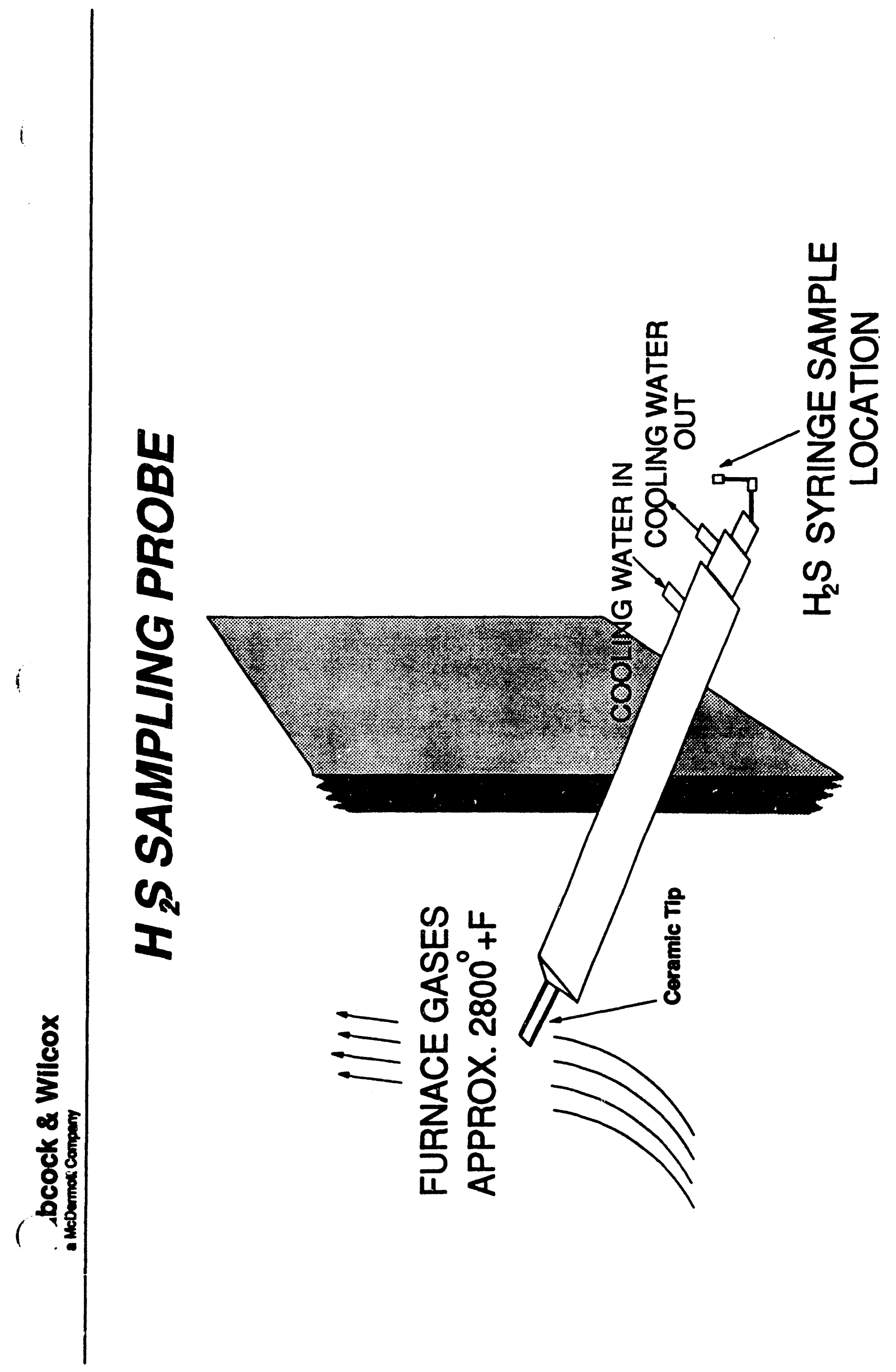




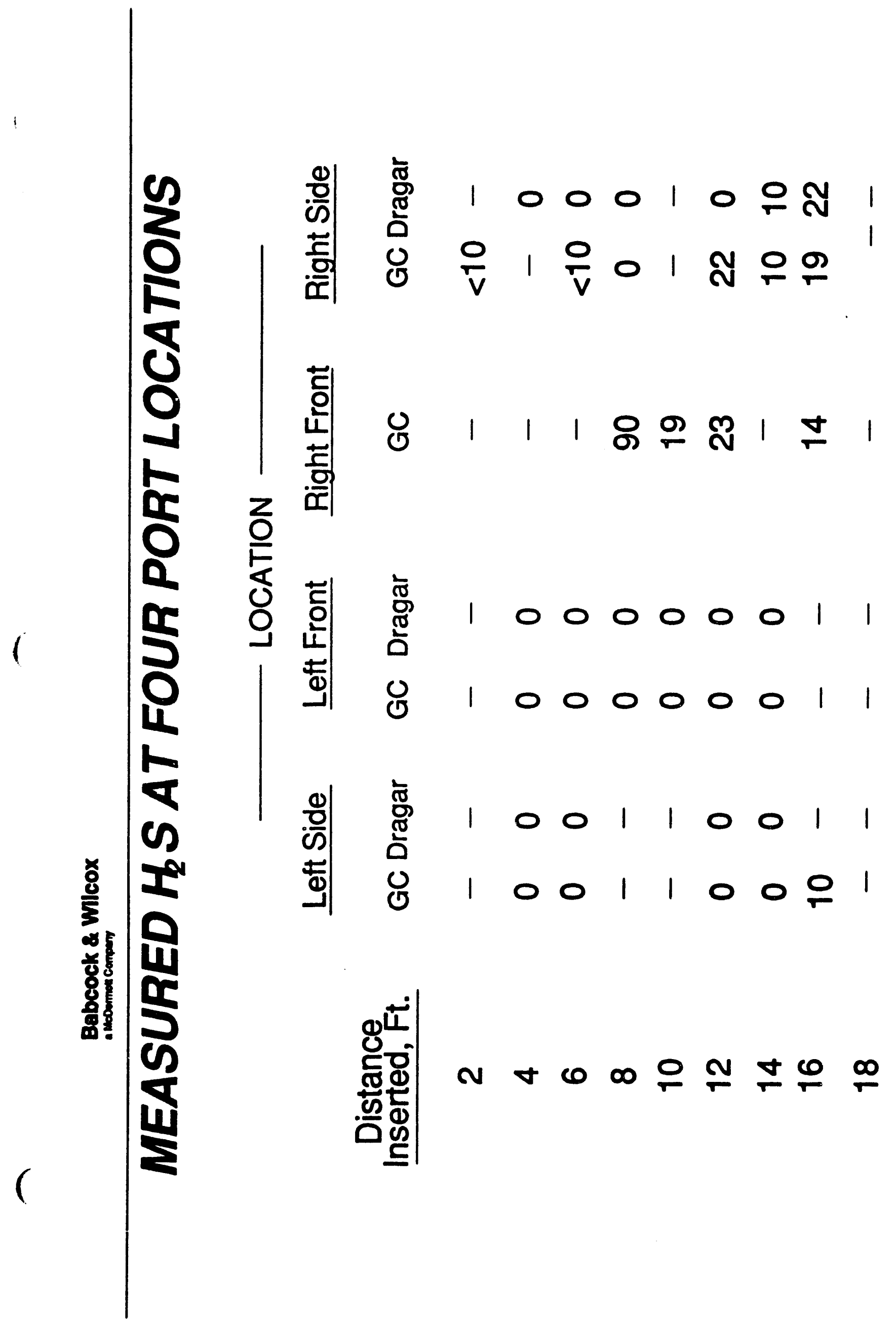




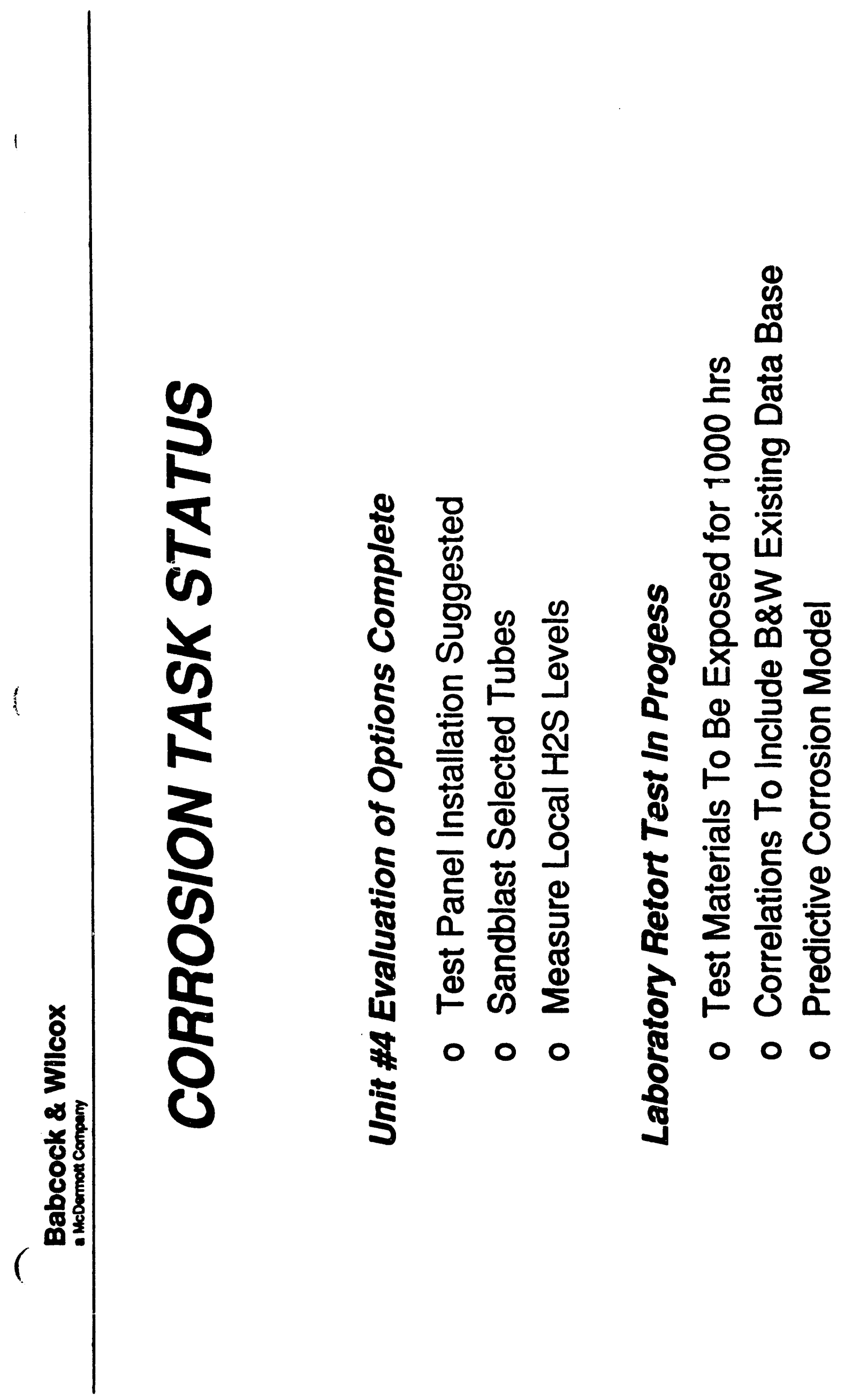




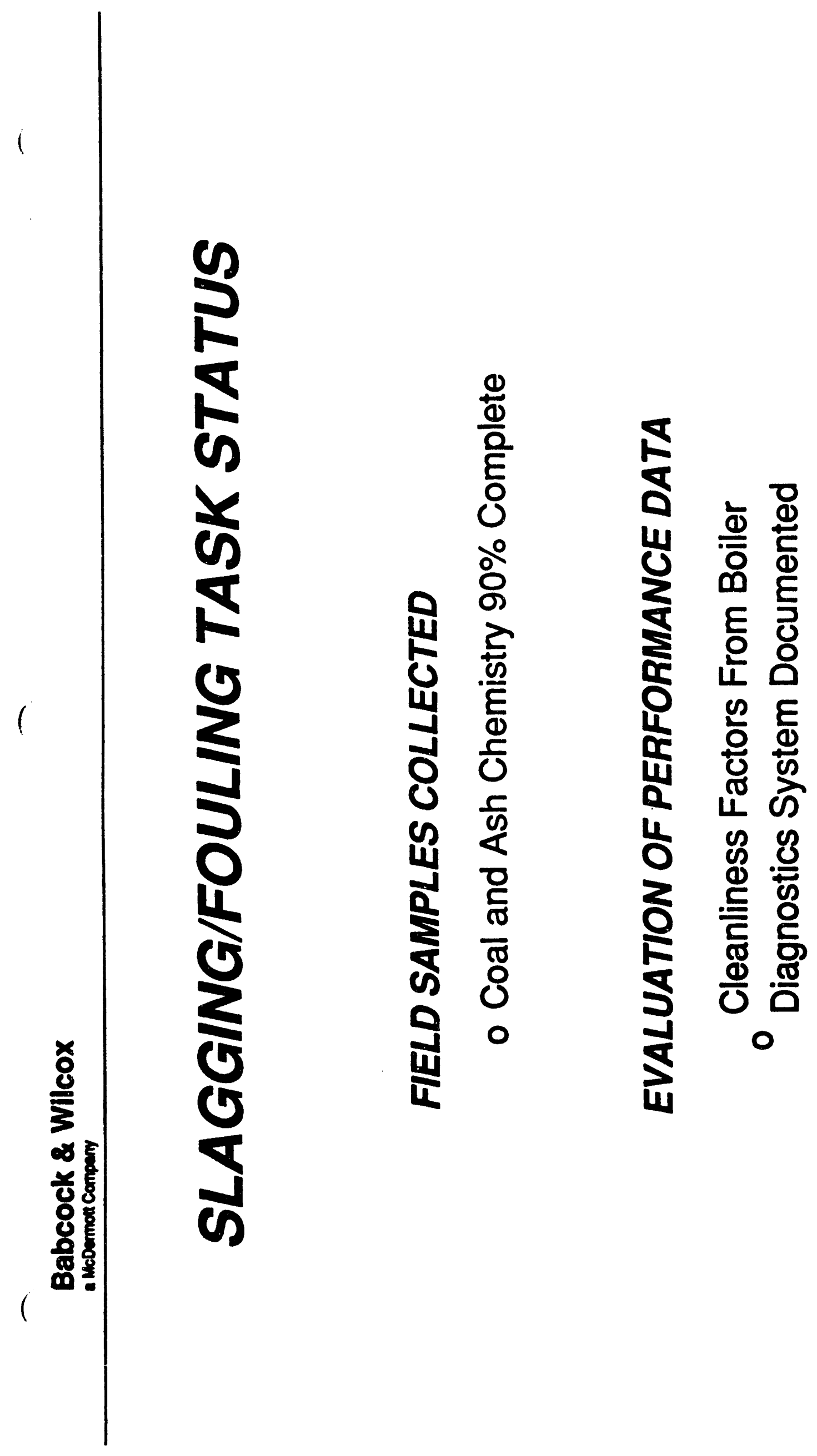




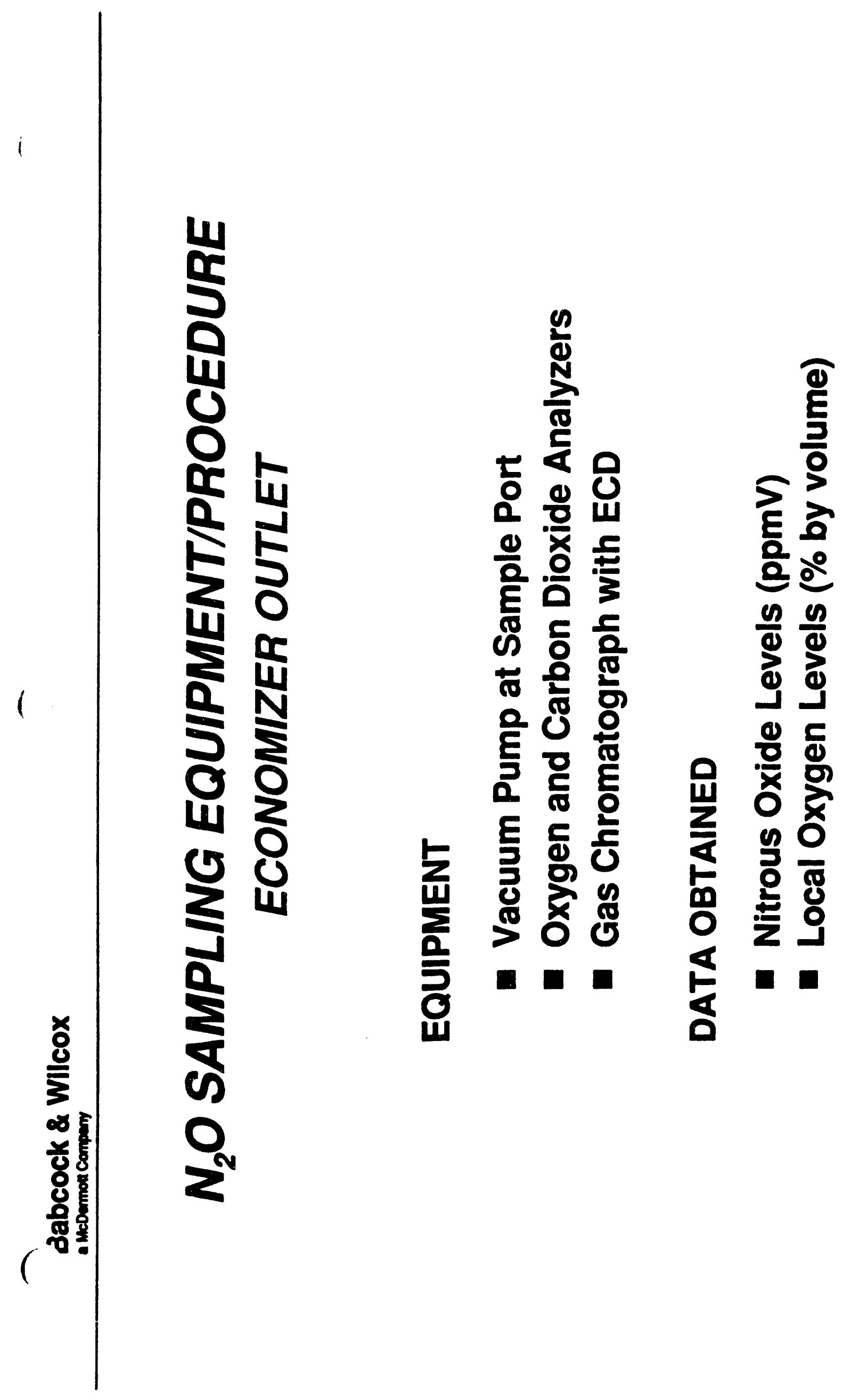




\section{$\mathrm{N}_{2} \mathrm{O}$ AT ECONOMIZER OUTLET Comparison With 0.33ppm NIST Standard}

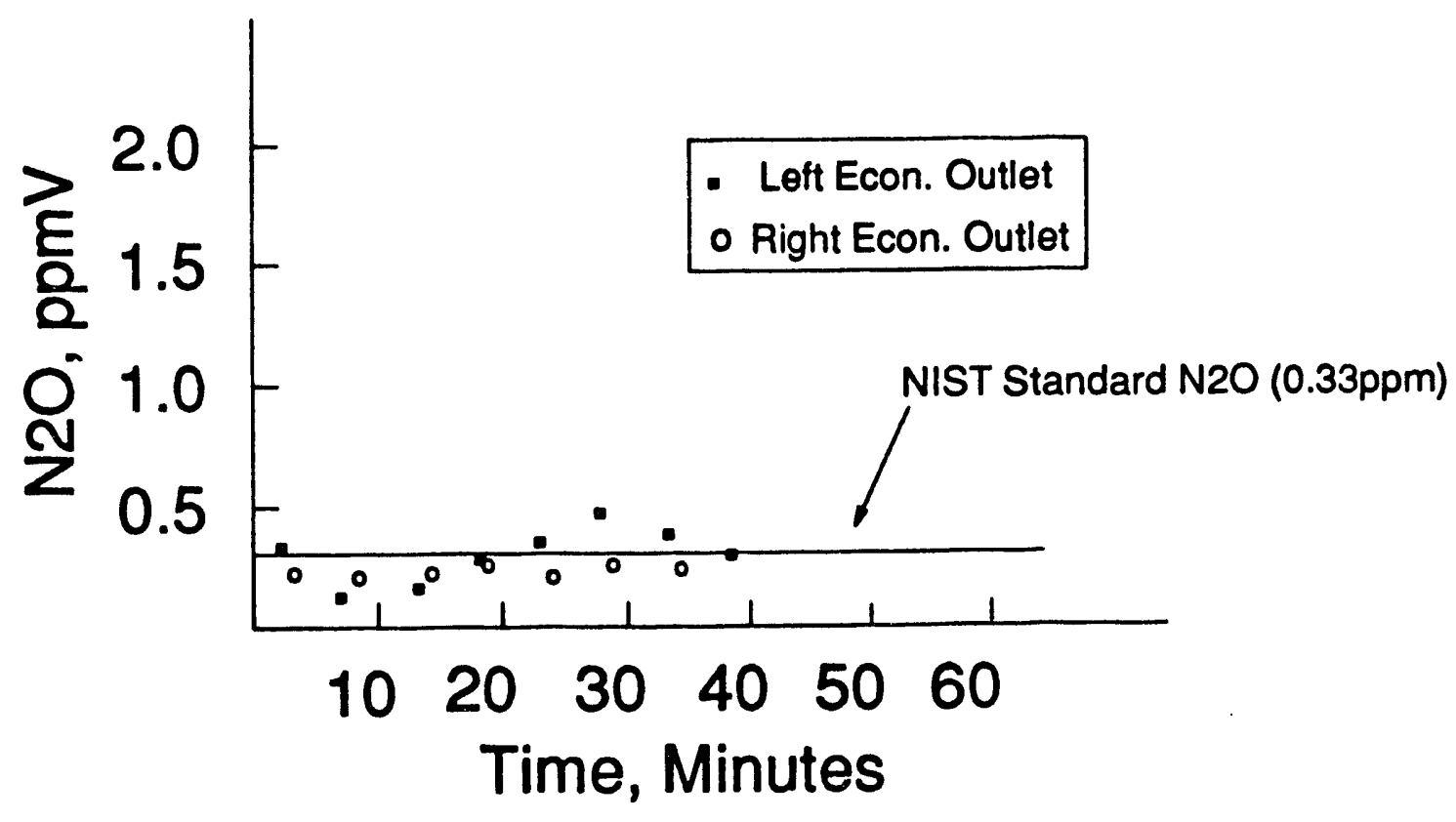


APPENDIX C 


\section{J. M. STUART STATION UNIT \#4}

LOW NOX BURNER CONTROLS OVERVIEW

Contracted with SEGA to design controls

Six PLCs - one per Mill group

Two motor control cabinets

- 30 KVA - 480 to 120v transformer

- 24 breakers and reversing contacts

24 NEMA interface junction boxes

48 Jordan Actuators

- 6.8 full load amps

- 13.2 stall motor amps

- 5.2 no load amps

Original System

- Limitorques with 13 contacts

- Multiconductor cable

- 208 v @ 4.0 full load amps 


\section{AIR REGISTERS \\ $24 E A C H$}

\section{HOFFMAN TMPE BOXNEAR BURNER}

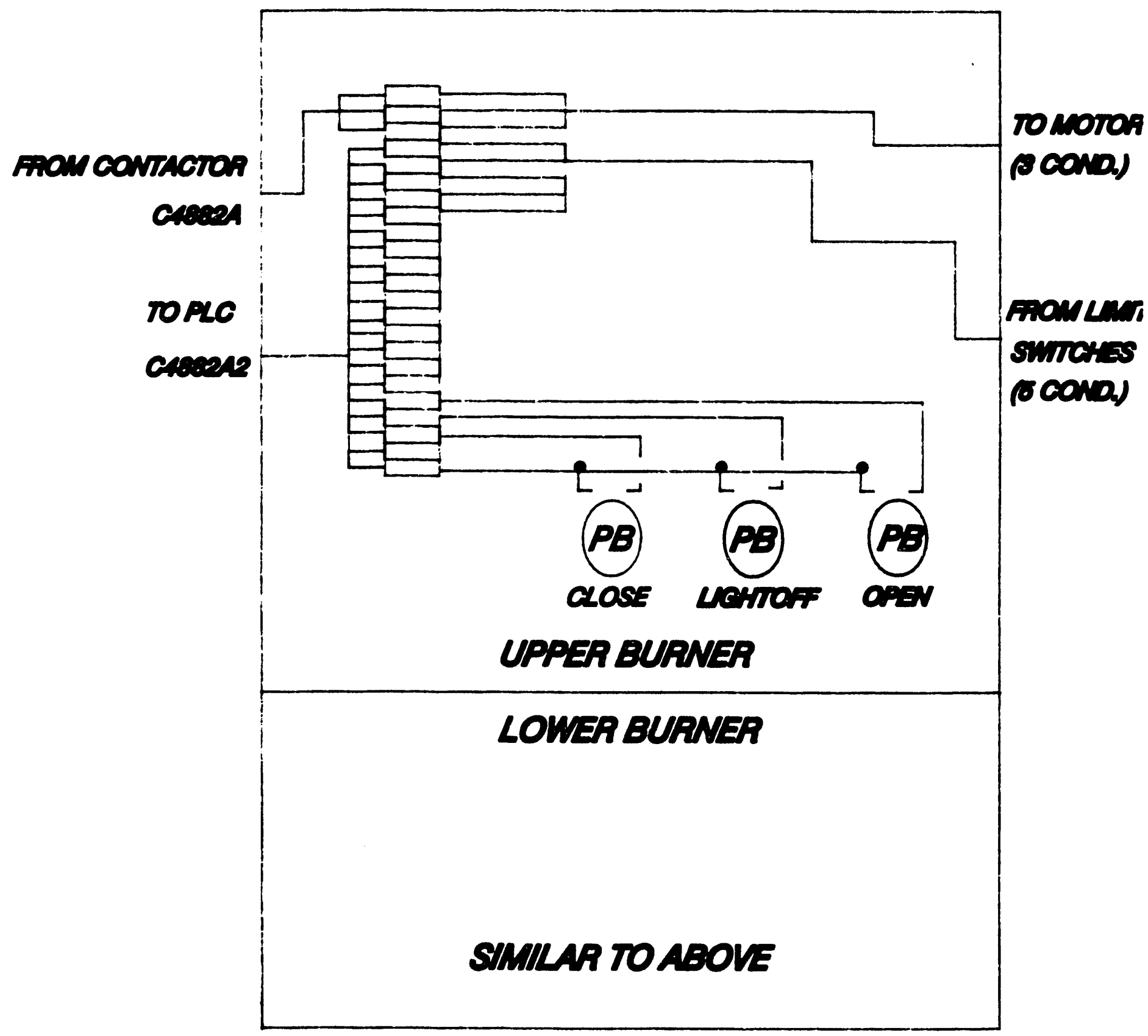




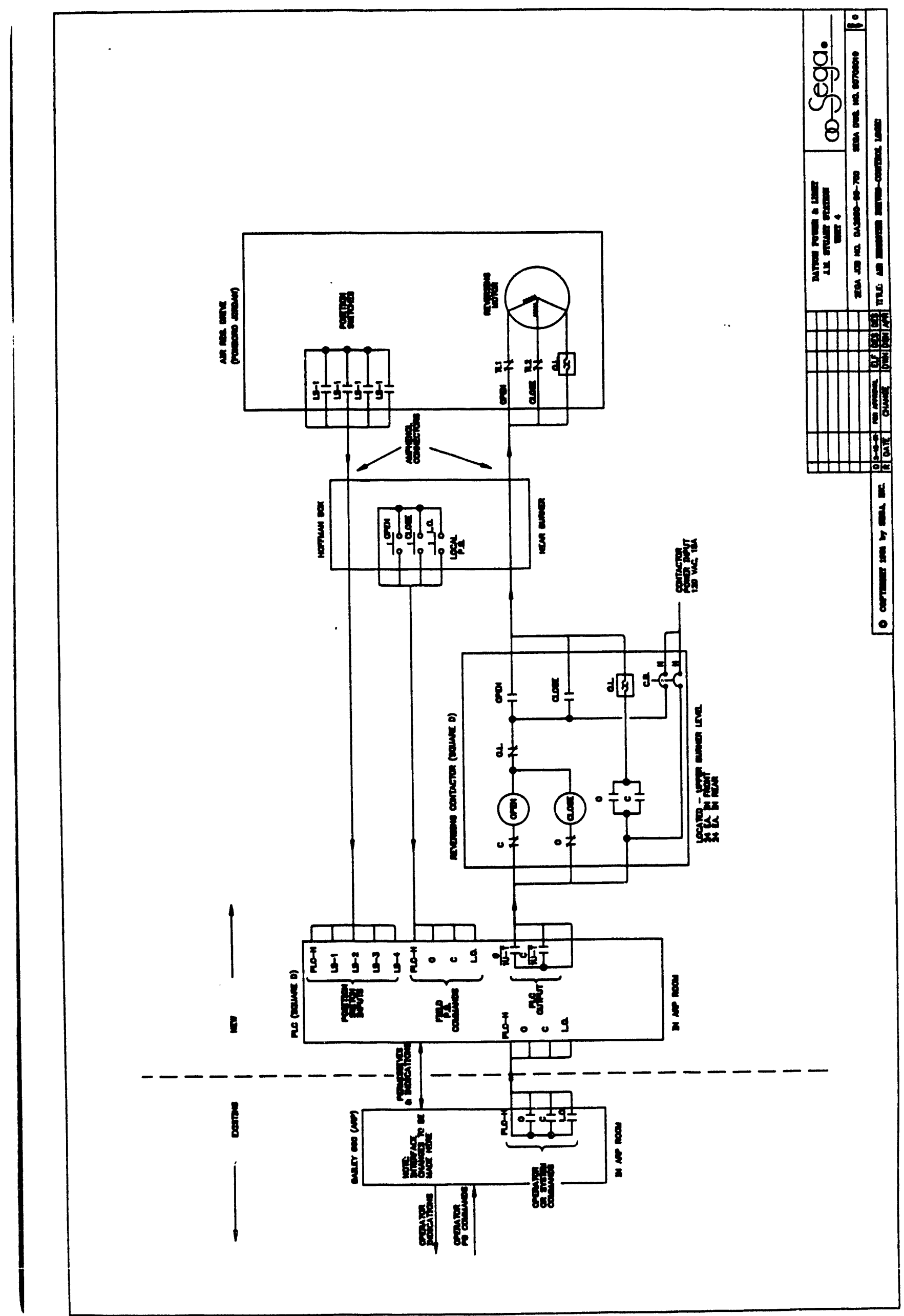


APPENDIX D 


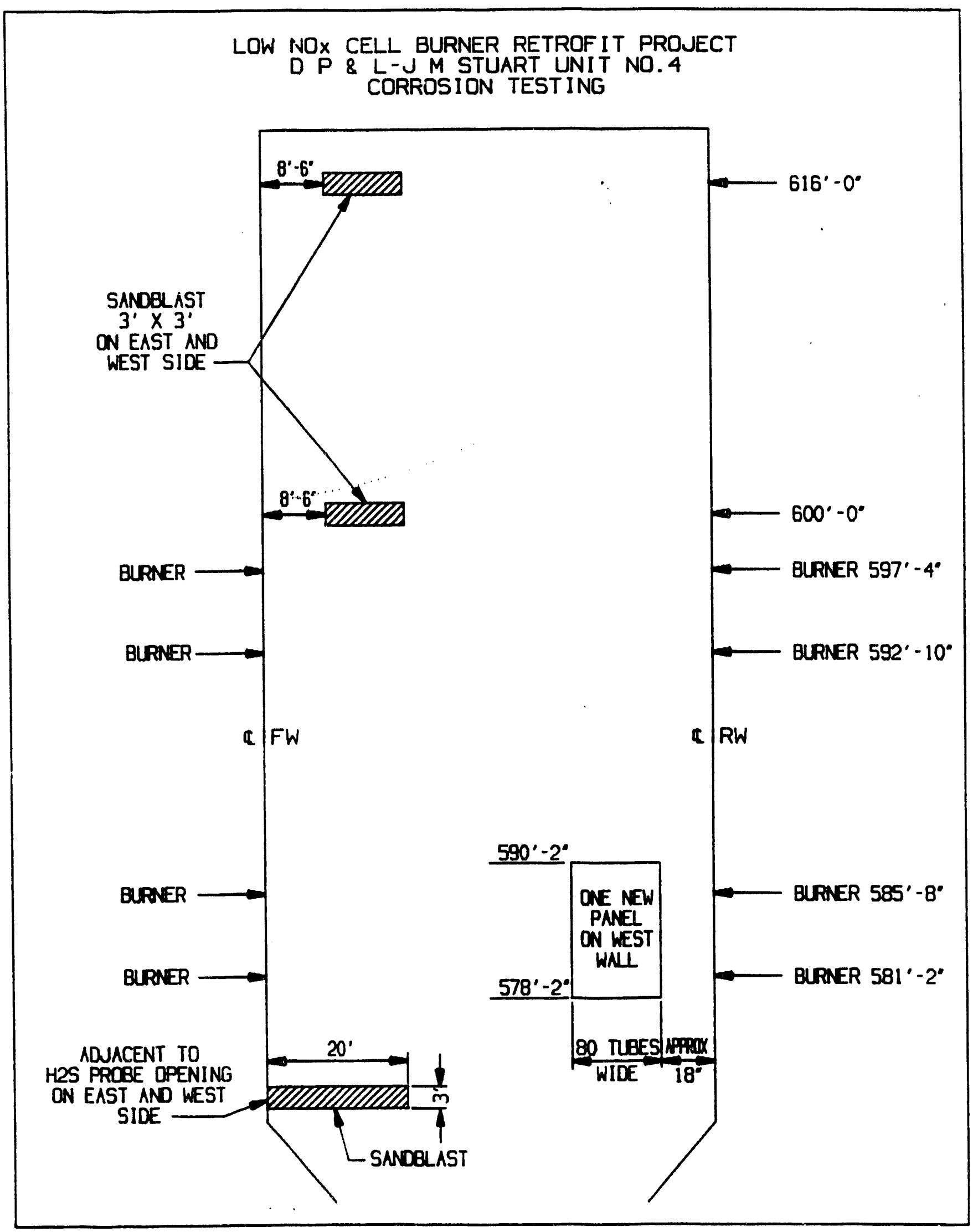

Gifh neterer-5 
Low nOx Cell Buríier Retrofit Project New Corrosion Test Panel

80 TUBES WIDE CONSISTING OF THE FOLLOWING MATERIALS (APPROX. 10 TUBES EACH):

\author{
SA213T2 BARE \\ SA213T22 BARE \\ SA213T91 BARE (OR SA213T9) \\ SA213T2 WITH EITHER \\ TP304H WELD OVERLAY OR \\ BI-METALLIC T2/TP304H \\ SA213T2 WITH 2 COATINGS
}

Panel would also require:

4 TEMPERATURE THERMOCOUPLES

4 PORTS TO SAMPLE $\mathrm{H}_{2} \mathrm{~S}$ 

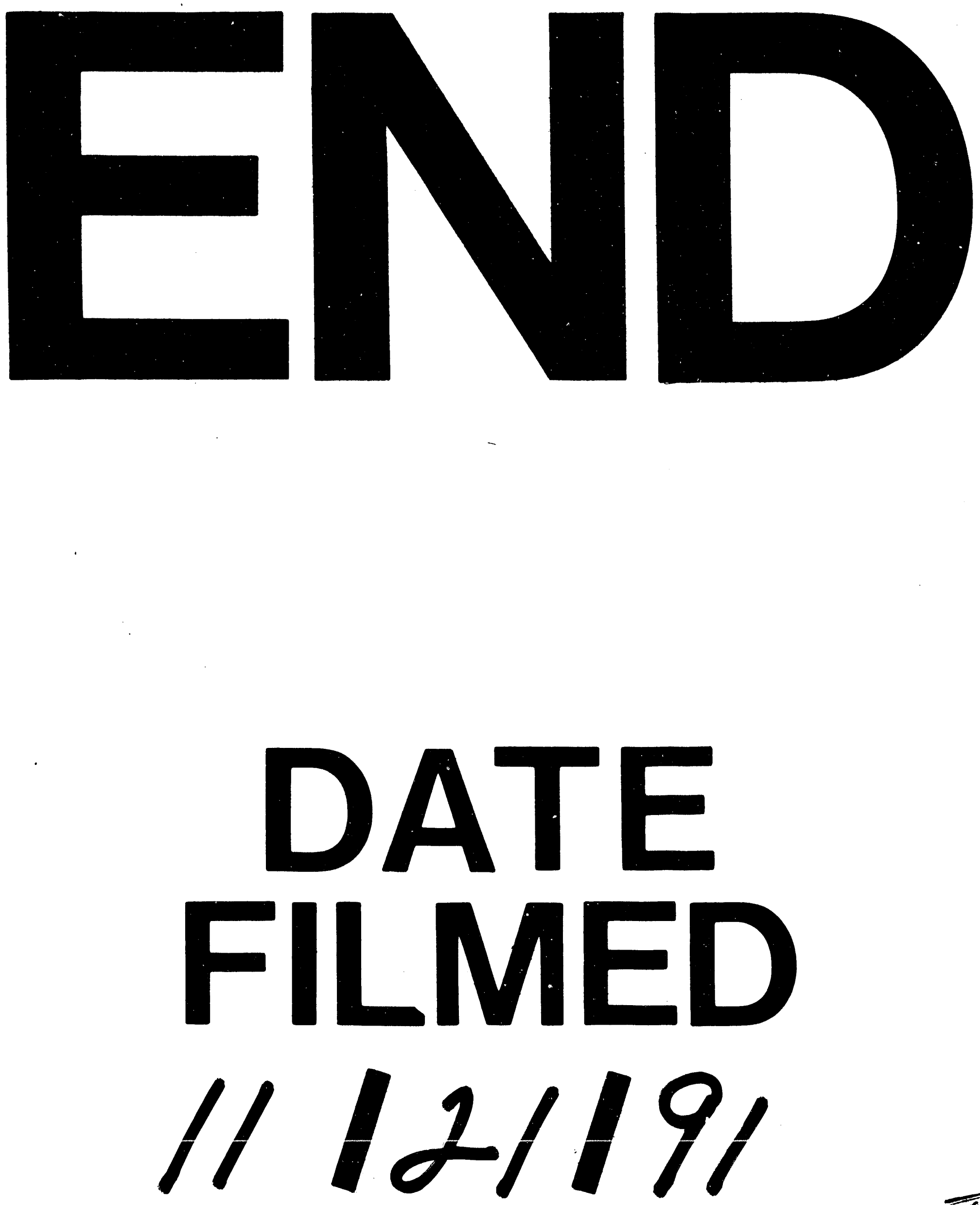

I 